\title{
Mercury Control with Calcium-Based Sorbents and Oxidizing Agents
}

\author{
Topical Report
}

For period Sept. $5^{\text {th }} 2001$ through May $31^{\text {st }} 2002$

Principal Investigator: Thomas K. Gale

Report issued in June 2002

DE-FC26-01NT41183

Southern Research Institute $20009^{\text {th }}$ Ave South

Birmingham, AL 35205

ARCADIS G\&M

4915 Prospectus Drive, Suite F

Durham, NC 27713 


\title{
Disclaimer
}

This report was prepared as an account of work sponsored by an agency of the United States Government. Neither the United States Government nor any agency thereof, nor any of their employees, makes any warranty, express or implied, or assumes any legal liability or responsibility for the accuracy, completeness, or usefulness of any information, apparatus, product, or process disclosed, or represents that its use would not infringe privately owned rights. Reference herein to any specific commercial product, process, or service by trade name, trademark, manufacturer, or otherwise does not necessarily constitute or imply its endorsement, recommendation, or favoring by the United States Government or any agency thereof. The views and opinions of authors expressed herein do not necessarily state or reflect those of the United States Government or any agency thereof.

\begin{abstract}
The initial tasks of this DOE funded project to investigate mercury removal by calcium-based sorbents have been completed, and initial testing results have been obtained. Mercury monitoring capabilities have been obtained and validated. An approximately 1MW (3.4 $\mathrm{Mbtu} / \mathrm{hr}$ ) Combustion Research Facility at Southern Research Institute was used to perform pilot-scale investigations of mercury sorbents, under conditions representative of full-scale boilers. The initial results of ARCADIS G\&M proprietary sorbents, showed ineffective removal of either elemental or oxidized mercury. Benchscale tests are currently underway to ascertain the importance of differences between benchscale and pilot-scale experiments. An investigation of mercury-capture temperature dependence using common sorbents has also begun. Ordinary hydrated lime removed 80 to $90 \%$ of the mercury from the flue gas, regardless of the temperature of injection. High temperature injection of hydrated lime simultaneously captured $\mathrm{SO}_{2}$ at high temperatures and $\mathrm{Hg}$ at low temperatures, without any deleterious effects on mercury speciation. Future work will explore alternative methods of oxidizing elemental mercury.
\end{abstract}




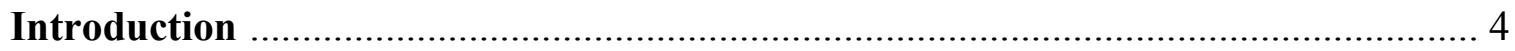

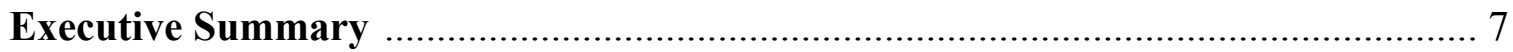

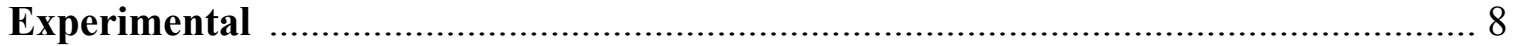

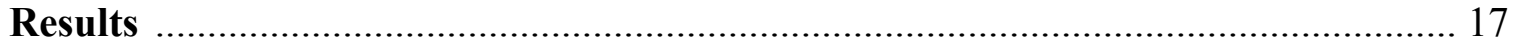

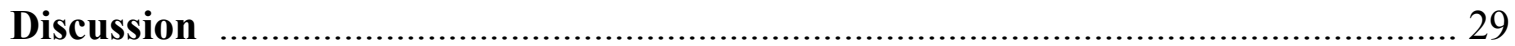

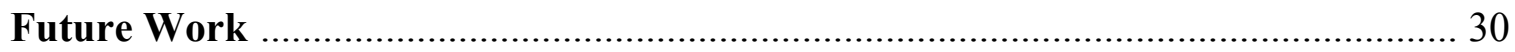

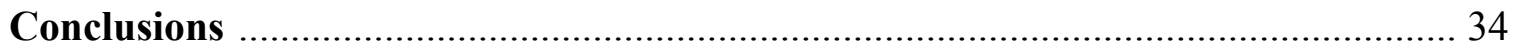

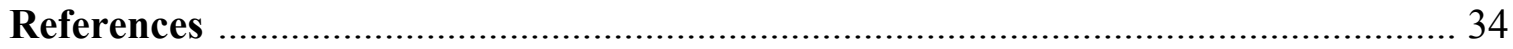

Figure

List of Figures $\quad$ Page

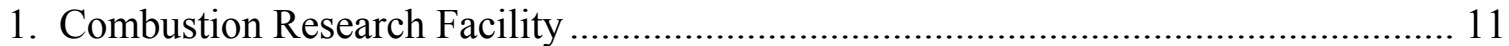

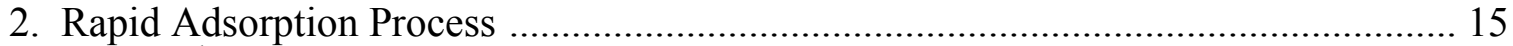

3. Dec. $12^{\text {th }}$ : Comparing Ontario Hydro with PSA Monitor measurements ................... 19

4. Dec. $13^{\text {th }}$ : Comparing Ontario Hydro with PSA Monitor measurements .................. 20

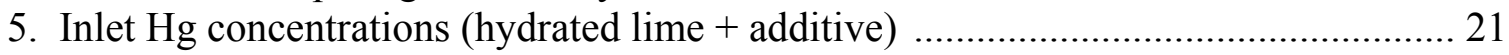

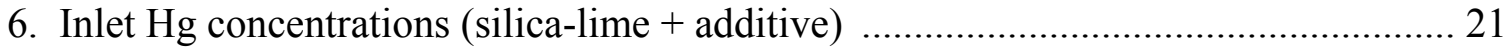

7. Variation of coal feed Hg concentrations ………….............................................. 22

8. Outlet $\mathrm{Hg}$ concentrations (hydrated lime + additive) ................................................ 23

9. Outlet $\mathrm{Hg}$ concentrations (silica-lime + additive) ………............................................ 23

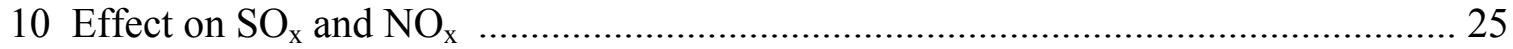

$11 \mathrm{Hg}$ removal by hydrated lime in baghouse ........................................................ 27

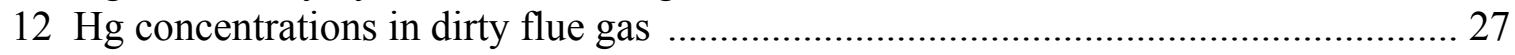

13 Mass balance of the Hg monitor measurements with coal feed ................................ 29

Table List of Tables $\quad$ Page

1. Choctaw America HvA Bituminous Coal .............................................................. 15

2. Flue gas composition after baghouse ................................................................ 17

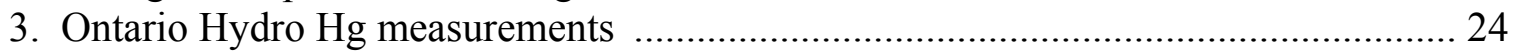

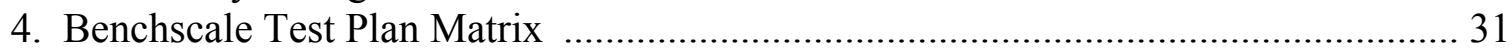

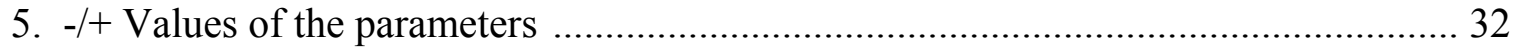

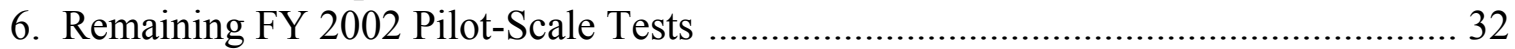

7. Parameters to be tested in the Year 2 matrix ........................................................... 33

8. Matrix of Experiments for Year 2 of the project ...................................................... 33 


\section{Introduction}

\section{$\underline{\text { Background }}$}

Atoms of mercury can neither be created nor destroyed. The amount of mercury in the earth's biosphere is approximately constant. Natural volcanic activity does bring significant amounts of mercury to the earth's surface. However, other processes provide environmental sinks for the naturally emitted mercury in the earth's crust and in the atmosphere above its surface. Much of the mercury found in the ground and in the bottom of the ocean or other bodies of water is buried in the soil or sediment at sufficient depths to present no threat to the environment or human health. Also, natural mercury on the surface of the earth is often found in the stable and relatively benign $\mathrm{HgS}$ form. The real threat of mercury to human health and the environment is the re-entrainment of mercury into the atmosphere and its transport directly or indirectly to particular sediment/water surface separation layers, where the mercury can be transformed into a much more dangerous organic form and bioaccumulated in aquatic life.

Mercury emissions from coal fired power plants, although of very low concentration in stack gases, collectively constitute the largest source of mercury emissions to the environment in the United States, due to the large number and scale of operating boilers. Mercury is toxic in all its forms. However, the most toxic is the organic form, which is the form of bioaccumulation in the ocean, freshwater lakes, and aquatic life. Bioaccumulation provides an immediate sink for oxidized mercury and a continuous sink for the long residence time atmospheric elemental mercury emitted into the environment from natural and anthropogenic sources. Bioaccumulation also provides a direct path to human exposure. As a result of years of mercury emissions from power production and other industrial processes, the concentration of methyl mercury (the organic form) in the fish of many freshwater lakes in the United States has risen to the level where the fish are unsafe for human consumption. Consequently, the number of freshwater lakes where commercial or sport fishing is allowed is shrinking. Oceanic aquatic life has also been adversely affected, particularly in the Gulf of Mexico, where the methyl and dimethyl $\mathrm{Hg}$ concentrations in fish continue to rise, particularly in the increasingly popular predator fish, such as tuna, amberjack, shark, redfish, swordfish, cobia, large mackerel, and grouper. The bioaccumulation of mercury in our lakes and rivers will continue to increase the organic mercury intake by humans and eventually create other pathways of exposure to the human population.

One method of preventing mercury emissions from coal-fired power plants is to use activated carbon based sorbents with oxidizers to capture mercury before it escapes the stacks. However, activated carbon sorbents are expensive and create ash utilization and disposal problems. Consequently, this project looks at using calcium and calcium-silica based sorbents with oxidizers as potential alternatives to activated carbon in flue-gas mercury removal systems. Calcium-based sorbents are not only potentially cheaper than activated carbon sorbents, but they also should create a more environmentally benign ash product.

Scope of Work - As Presented in the Cooperative Agreement Notice of Financial Assistance Award

The scope of work is intended to provide the necessary information to assess the effectiveness and cost of calcium-based sorbents for controlling mercury from coal-fired utilities by performing pilot-scale testing of lime and silica-lime-based sorbents with a selected oxidant. 
Sorbent effectiveness will be evaluated with a variety of coal types, operating conditions, and emission control system options for particulate control and $\mathrm{NO}_{\mathrm{x}}$ reduction. The possible field tests and pilot plant testing will be supported by bench-scale sorbent optimization studies.

Testing of the sorbents will be performed in the Southern Company/Southern Research Institute Combustion Research Facility. ARCADIS Geraghty \& Miller will provide bench-scale support with sorbent production tasks using EPA facilities at Research Triangle Park, NC. If pilot-scale testing is successful, utility host-sites may be identified to test at large scale.

For clarity and order, the above scope of work has been organized into the following 4 areas of focus:

Area of Focus 1: Intimately Associated Sorbents and Oxidants

This Area of Focus primarily involves ARCADIS development of proprietary sorbents-withadditives and testing of these ARCADIS proprietary sorbents in the CRF at SRI. This is a low temperature investigation, where an attempt is made to simultaneously capture $\mathrm{SO}_{\mathrm{x}}$ and mercury.

Area of Focus 2: Separate Injection of Sorbents and Oxidants

This Area of Focus involves investigating common sorbents, such as hydrated lime, kaolin clays, bauxite, limestone, dolomite, pulp and paper waste residues, and other industrially accepted sorbents. Oxidants will be injected separately from the sorbents, before or after the sorbent injection location, to effect the most advantageous strategy for total mercury removal (i.e., elemental and oxidized).

\section{Area of Focus 3: Alternative Means of Oxidation}

An alternative to additives designed to promote elemental mercury oxidation will be investigated in this Area of Focus. Combustion modifications and temperature time history modifications in conjunction with an appropriate sorbent injection strategy may allow near complete capture of total mercury using cheap and commercially available common sorbents, such as those mentioned in Area of Focus 2.

\section{Area of Focus 4: Temperature Dependence}

The temperature dependence of mercury capture will be explored for the temperatures of sorbent injection, oxidant injection, and location of mercury capture (sampling temperature). Understanding the temperature dependence of these three parameters are vital to a mechanistic understanding of the mercury capture process, which is necessary for further development and implementation of these mercury emission mitigation technologies into full-scale industrial boilers.

\section{Accomplishments}

Task 1 was completed. A PSA mercury monitor with two gas conditioning systems was installed and tested at SRI's pilot-plant in preparation for the first run week of sorbent testing. In 
addition, the RAP (Rapid Absorption Process) system was tested the first week of December. The shakedown test was positive. In February, the RAP tube was used in once-through operation (duct injection test) to provide a two-second sorbent residence time to capture sulfur and mercury before the sorbent collected on the bags of the Fabric Filter, where mercury continued to be captured. A plant baseline characterization test was performed in December as well, to assess the inherent speciation of mercury in the pilot-plant facility. Based on the qualification test, the CRF was deemed favorable for testing the ability of oxidizing agents to oxidize elemental mercury before capture.

In addition, a week of mercury monitoring using the PSA monitor was performed in January, 2002, piggy-backing on another project. This week of monitoring was important in terms of obtaining operational experience with the monitor and developing the ability to obtain good data. The PSA monitor is not a plug-and-play piece of equipment, particularly for sampling in a dirty flue-gas stream. Therefore, sampling and monitoring procedures were developed and modifications were made to the gas sampling system to allow more effective operation.

Task 2.1 was completed last year when ARCADIS G\&M performed a sorbents optimization study, the results of which identified two different sorbent/oxidizer combinations to test at the pilot-scale test facility. ARCADIS has been working on sorbent development for the last ten years. The details of their work on mercury sorbents can be found elsewhere [1-3].

Task 2.2 was performed by ARCADIS G\&M, who prepared and delivered sorbents for the February 2002 test.

Task 2.3 was completed during the February test run. ARCADIS personnel performed an on-site audit of the Ontario Hydro measurements and the PS Analytical mercury monitor operation. The results of the initial audit were favorable, except for a few items that were a result of a misunderstanding by the auditors of the CRF system and the procedures of the SRI staff. These misunderstandings have been cleared up in a response of SRI to the ARCADIS auditors. The net result of this task was (1) to improve SRI's understanding of and ability to make mercury measurements and (2) validation of the data that SRI has obtained and will obtain in this project. Per DOE's request, the audit findings are currently being reviewed by Jeff Ryan of EPA.

Task 3 has been started, and is proceeding as anticipated, with significant changes to the test matrix. Due to the results of the February tests, ARCADIS will perform a set of benchscale experiments to help answer questions raised about their sorbents. This task continued in April with base-line testing of (1) hydrated lime, (2) dust cake capture, (3) disperse phase capture, (4) Apogee Probe testing and validation, (5) high temperature sorbent injection, (6) sorbent injection dependence testing, and (7) sampling temperature dependence. Other experiments planned include, duct injection of mixtures of hydrated lime and kaolinite at various temperatures and alternative ways to add oxidant. Tests will be performed where oxidant is added in the duct, rather than with the sorbent. Various forms of oxidant (i.e., chlorates, $\mathrm{Cl}_{2}$ gas, sodium tetrasulfide, etc.) will be added to the flue gas in a variety of configurations.

Tasks 4 and 5 began with the February testing and continued in April, and significant progress was made in this area. As discussed in the experimental, results, and discussion sections of this 
report, an assessment of the effectiveness of duct injection of the optimized sorbents provided by ARCADIS has been made, and validation of the PSA monitor measurements was obtained. In the future, most of the experiments will not involve Ontario Hydro mercury speciation measurements. Using only the PSA monitor to obtain mercury measurements (as in the April tests) will be much cheaper, more accurate, provide better and real-time data, and will allow many more experimental parameters to be tested in a shorter amount of time. In April, a baseline for mercury removal was obtained with hydrated lime. Both high temperature duct injection and collection in the baghouse were investigated. Several different temperatures of injection and sampling were investigated, thus embarking on work covered under Focus Area 4 of the Scope of Work.

Task 6 has been started. Two 38 liter (10-gallon) spent-sorbent/ash samples were sent to Ann Kim and Carl Schroeder at NETL, who will characterize the waste for long-term mercury retention.

Task 7 has begun with the submission of this topical report.

\section{Executive Summary}

Significant progress in this project of investigating calcium-based sorbents for mercury control was accomplished. Most of the project tasks were completed, specifically those related to preparation, mercury measurement, and quality checks were accomplished. The Combustion Research Facility (CRF) at Southern Research Institute (SRI) was prepared for testing sorbents and mercury monitoring. The PS Analytical monitor was installed, modified for measurement in dirty flue gas, and validated against Ontario Hydro measurements from a clean flue gas stream. It was also shown thereby that the Ontario Hydro method is ineffective for making mercury speciation measurements from particulate-laden flue gas streams. Also, an audit of methods, procedures and data, obtained by SRI personnel, was performed by ARCADIS auditors, specifically related to both Ontario Hydro and monitor measurements. However, the audit extended to all operations and procedures of the CRF. The overall result of the audit activities was to improve and validate SRI's capabilities to perform mercury measurements and assess the effectiveness of sorbent related mercury mitigation technologies.

Early on in the project, significant efforts and resources were applied to obtaining realtime mercury monitor capabilities. Initial efforts were spent on overcoming general operational pitfalls and developing a theoretical understanding of the PS Analytical monitor. Subsequent efforts addressed weaknesses in the PSA sampling system, particularly when sampling from a dirty flue-gas stream. Monitor measurements were validated against Ontario Hydro measurements and validated with mass balances, based on the coal feed rate and coal mercury content. The Monitor was adapted to an Apogee Scientific sampling probe, that allowed insitu separation of the ash and gas sample, without pulling the gas through a layer of ash, thus eliminating the adverse effects of sampling from a dirty flue gas stream. The result of the monitor development efforts thus far is that SRI has improved both the quality and quantity of their mercury measurement capabilities. SRI now has the capability to obtain 3 times as much data as originally anticipated with Ontario Hydro alone, and the data obtained will be better quality data and cheaper. 
The initial results of ARCADIS proprietary sorbent testing indicated that the mixed sorbent/fly-ash dust cake behaved much differently than the sorbent in the packed bed on the benchscale. Specifically, much less mercury was captured than anticipated, and the oxidant was ineffective. The difference in the flue gas composition may have had a significant impact. Benchscale experiments are currently underway to determine the importance of the major differences between the pilot-scale and benchscale experiments.

Hydrated lime duct injection was investigated at several different temperatures of injection. Mercury capture was assessed at several different temperatures by sampling at three different locations, including after the baghouse. Hydrated lime was successful at capturing between 80 and $90 \%$ of the total mercury on the bags of the baghouse, regardless of the injection temperature. The highest temperature of injection also removed $50 \%$ of the $\mathrm{SO}_{2}$ from the 1150 ${ }^{\circ} \mathrm{C}\left(2100{ }^{\circ} \mathrm{F}\right)$ flue-gas. Of interest was the effect of possible high temperature removal by the sorbent of chlorine radicals, which are important in the mercury oxidation process. However, no difference in mercury speciation was observed. This is relevant because sorbents may potentially be used to capture some air toxics at high temperature and subsequently capture mercury at low temperatures. Approximately $33 \%$ of the mercury was removed in the duct above $163{ }^{\circ} \mathrm{C}\left(325^{\circ} \mathrm{F}\right)$, before the baghouse, but no elemental mercury was removed. Also, above $288^{\circ} \mathrm{C}\left(550{ }^{\circ} \mathrm{F}\right)$, no mercury was captured by the hydrated lime when injecting at $1150{ }^{\circ} \mathrm{C}$.

\section{Experimental}

Due to the complex nature of mercury chemistry, thermodynamics, and kinetics in association with chlorine and other acid gases in coal-fired boilers, a fundamental understanding of mechanisms is necessary in order to apply calcium-based sorbent technology to capture mercury. Fundamental research is normally thought of as something done on a bench-top or small scale. For mercury however, the $1 \mathrm{MW}$ (3.4 million Btu/hr) Combustion Research Facility at SRI is about as small of a coal-fired power facility as can be used to study the fundamental parameters (kinetics, flue-gas composition, and competition) relevant to Hg-speciation, capture, and chemical and physical absorption in an actual coal-fired boiler. For furnaces any smaller in size, increased contact with wall surfaces causes reaction mechanisms to dominate that are only minor mechanisms in a full-sized boiler. Hence, the scope of work is intrinsically both a basic fundamental research project and an applied semi-industrial scale project. The project is being pursued from a fundamental basis, the mechanistic understanding from which may be directly applied to effect and enhance mercury capture through calcium based sorbents in full-scale boilers.

While all mercury is in the elemental form in the furnace, the mercury begins to oxidize as the gas cools (in the convective pass and following flue duct) and the acid gases react with the elemental mercury in the presence of exposed duct surfaces and coal fly ash. In addition to possessing a sufficiently small length to width ratio, the CRF has a temperature and velocity history through the furnace, the convective pass, and pollution control devices that is similar to a full-scale utility boiler.

Adel Sarofim and Connie Senior have done work on mercury speciation, kinetics, and modeling that validate the point that pilot-scale or larger is needed for fundamental work. SRI has been in contact with Reaction Engineering International (REI) about the data from this project. Specifically, Connie Senior has been provided data from this project to allow them to validate and improve their kinetic model. The kinetic model will be used to predict mercury 
speciation in the CRF, without any additional charge to this project for work performed by SRI or REI.

\section{Description of the Combustion Research Facility}

The Southern Company and Southern Research Institute Combustion Research Facility is located on the Birmingham, Alabama, campus of Southern Research Institute (SRI). The facility was designed and constructed by SRI under contract to Southern Company Services (SCS). SCS and SRI jointly own the facility, and SRI operates the facility under contract to SCS. However, SRI can also perform confidential research for outside parties, including other utilities, with the payment of a facility usage fee to SCS. The facility is designed for up to six million Btu per hour firing on natural gas or coal, which is equivalent to $1.75 \mathrm{MW}$ thermal or about $0.6 \mathrm{MW}$ electric.

The design of the facility was carefully chosen to provide a close simulation of the physical processes that occur in a full-scale utility boiler. The facility, shown in Figure 1, consists of a coal crushing and milling area, a coal feeding system, a vertical refractory lined furnace, a single up-fired burner, a horizontal convective section pass with air-cooled tube banks, a series of heat exchangers, an electrostatic precipitator, a pulse jet baghouse, and a packed column scrubber.

\section{Fuel Preparation}

The fuel preparation area includes an open area storage yard, covered on-site storage bins, a rotary drum coal crusher, a CE Raymond bowl mill, and pulverized coal storage. Eight storage bins, each capable of holding up to 25 tons of coal or other fuel, are located adjacent to the coal preparation area. Approximately one acre of additional fuel storage space is available in front of the facility. As-mined coal is loaded into the crusher with a small front-end loader and is crushed to a size of minus $0.95-\mathrm{cm}(3 / 8$-inch). From the crusher, the coal is transported via a screw feeder and bucket elevator to one of two $3.5-\mathrm{m}^{3}\left(125-\mathrm{ft}^{3}\right)$ storage bins located beside the mill. These bins are independently located on load cells and are equipped with integral vibrator/bridge-breakers and rotary lock feeders. The facility digital control system (DCS) is used to set the discharge rate for each bin so that combinations of different fuels can be fed to the mill while providing mass flow information for use with determining precise material balances for each fuel. The discharges of both hoppers is combined and fed to the mill. Fuel samples can be obtained from any part of the process.

The coal mill is a refurbished and instrumented Model 352 CE-Raymond bowl mill, which has a rated capacity of 2 tons per hour. This type of mill should give representative milling simulations of the different air-swept table and roller mills normally used in power plant service. The mill air is preheated with a dedicated natural gas burner, which also helps inert the mill. For fuels that present an ignition hazard such as Powder River Basin coals and some biofuels, the facility is equipped to accept additional inerting from nitrogen tank trucks. The mill is instrumented to report roller spring pressure, journal lift, motor amperage and voltage, gas flow, and mill rejects to the facility DCS.

Pulverized coal is captured in an Ultra Industries CF-41-8 pulse-jet baghouse and transported through a dedicated dense phase transport system to either an inerted pulverized fuel storage hopper (adjacent to the furnace) or to an inerted, separate waste hopper. Both hoppers 
are located on load cells. In such small-scale pulverized coal firing, it is normal practice to use indirect firing to help eliminate coal surges which can cause flame stability problems. The mill circuit can also be used to perform stand-alone milling experiments.

\section{Coal Feeding}

The coal feeding system is designed to deliver a constant feed of pulverized coal to the burner. The storage hopper is equipped with an orbital-motion live bottom to prevent bridging or rat-holing of the fuel. An Acrison loss-in-weight auger-type feeder weighs a controlled amount of fuel that is discharged into the primary air line through a rotary airlock valve. This gravimetric feeder is suspended on a weighing mechanism, and varying the auger speed maintains the desired fuel feed rate.

\section{$\underline{\text { Radiant Furnace }}$}

The furnace is a vertical, up-fired $8.5-\mathrm{m}$ (28-foot) high cylinder, with an inner diameter of $1-\mathrm{m}$ (3.5 feet) (see Figure 1). This allows gas velocities of 3 to $6 \mathrm{~m} / \mathrm{s}(10$ to $20 \mathrm{feet} / \mathrm{s})$ and residence times of 1.3 to 2.5 seconds, depending upon the firing rate. The design furnace exit gas temperature is $1200^{\circ} \mathrm{C}\left(2200^{\circ} \mathrm{F}\right)$.

The body of the furnace is built of seven 1.2-m (4-foot) tall sections, each being a water-cooled jacket with 10 -cm (4-inches) of refractory lining cast on the fireside. This refractory lining is used to limit the heat extraction and to ensure the proper simulation of the radiation environment found inside full-scale furnaces. Small furnaces have much higher ratios of inside surface area to total volume than full-scale furnaces, and the flame would be quenched if the entire interior was lined with heat exchange surface. The furnace diameter and height were chosen to best match the velocities and residence times found in full-scale units, with a velocity of $6 \mathrm{~m} / \mathrm{s}$ ( 20 feet/s) and a residence time to the furnace exit of 1.2 seconds chosen, at full firing rate.

\section{Burner Assembly}

The burner is mounted coaxially on the bottom of the furnace and is up-fired using natural gas, pulverized coal, any combination of the two or any other fuel that can be finely divided and transported to the pulverized coal silo. It is equipped with a flow control system for secondary air flow and a set of registers which impart swirl to the secondary air, separate from the flow control. The secondary air and the primary air-coal mixture enter the furnace through a refractory quarl with a $25^{\circ}$ half angle. Two clean-out ports are provided in this section, to allow bottom ash to be periodically removed from the furnace. A closed-circuit television camera with a control-room monitor allows constant monitoring of the view of the flame from the top of the furnace. A low NOx. firing system, consisting of the a generic dual-register burner and an overfire air system, can be installed to simulate several combinations of low NOx, firing.

\section{Convective Sections}

The combustion gases exit the vertical furnace through a horizontal convection pass that is designed to remove a substantial part of the heat from the flue gases. The extraction of heat is 
designed to simulate the time-temperature profile found in a utility boiler. A series of three air-cooled tube banks are installed in the convective pass, and the air cooling is used to control either the temperature profile of the flue gases or the tube metal surface temperatures for fouling/ash deposition studies. A cross-flow tubular air preheater follows the convective tube banks and is used to preheat the primary and secondary air. Finally, four air-to-flue-gas recuperators are used to cool the flue gas down to a nominal $300^{\circ} \mathrm{F}$ before the flue gas enters the pollution control devices, which are described below.

The convective section is $0.46 \mathrm{~m} \times 0.46 \mathrm{~m} \times 6.7 \mathrm{~m}$ ( 1.5 feet $\times 1.5$ feet $\times 22$ feet), providing gas velocities of 9 to $18 \mathrm{~m} / \mathrm{s}$ (30 to 60 feet/s) and residence times of 0.4 to 0.8 seconds, again depending upon the firing rate. The design temperature range for the convective section is 1200 to $650{ }^{\circ} \mathrm{C}\left(2200\right.$ to $\left.1200{ }^{\circ} \mathrm{F}\right)$.

\section{SOUTHERN RESEARCH COMBUSTION RESEARCH FACILITY}

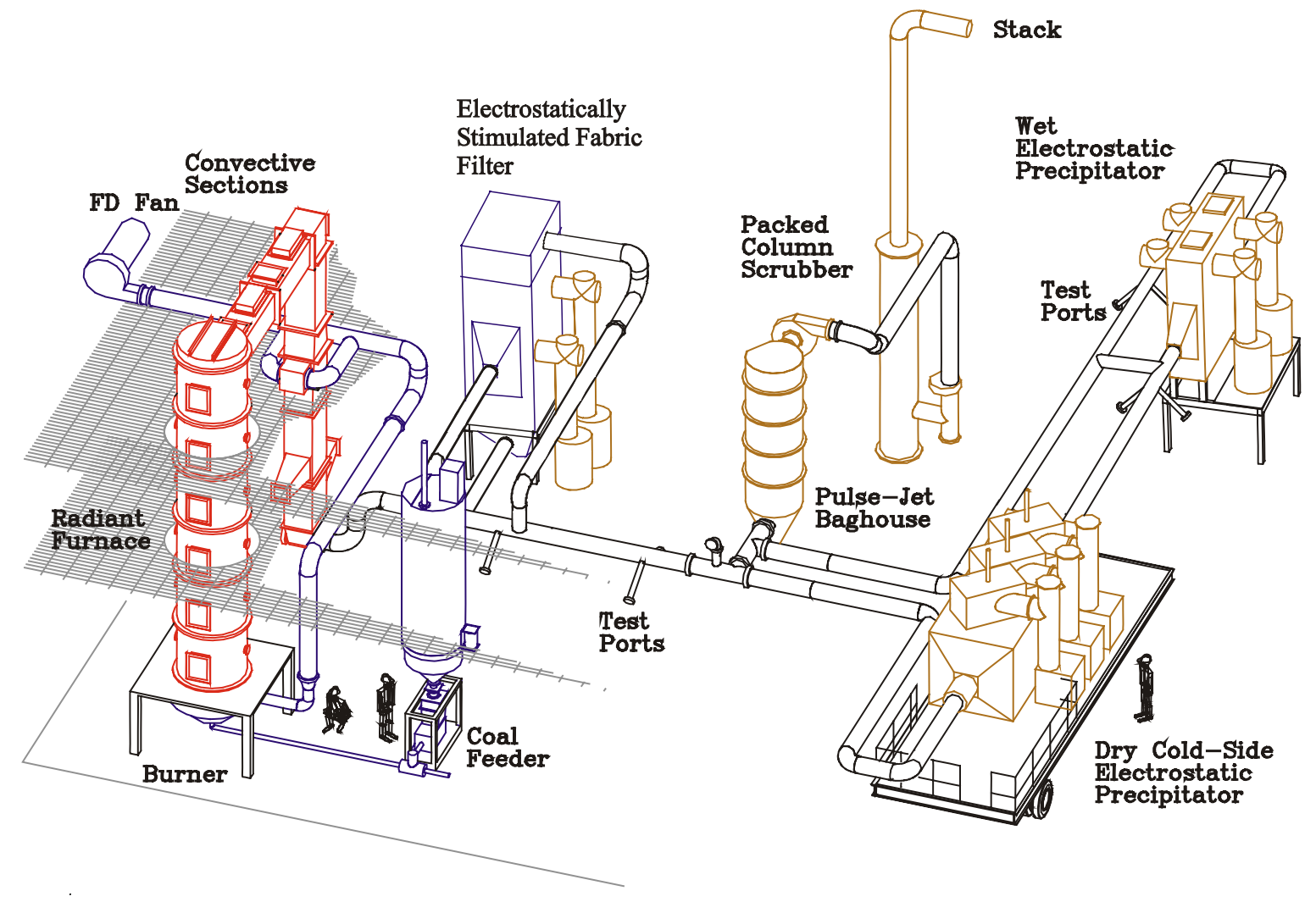

Figure 1. Current Combustion Research Facility Lay-out

\section{Computer Data Acquisition and Control System}

The facility is controlled and monitored by networked combined digital control system (DCS) and data acquisition computers, managed by Yokogawa CS-1000 system software that runs under the Windows NT operating system. This DCS performs all process control for the 
facility and allows complex feed-forward and calculated variable control. This computer control also performs the safety monitoring needed for safe operation of combustion equipment, including flame scanning and interlocks, automatic startup and automatic shutdown of the entire facility. Process data acquisition and storage is accomplished within the Yokogawa software.

\section{$\underline{\text { CEM System }}$}

A complete, extractive, continuous emissions monitoring (CEM) system is installed in the facility, and it is also interfaced to the computer control system. A set of gas analyzers, which analyze the flue gas for concentrations of $\mathrm{O}_{2}, \mathrm{NO}_{\mathrm{x}}, \mathrm{SO}_{2}, \mathrm{CO}_{2}$, and $\mathrm{CO}$, receives the dry flue gas sampled from a set of three extractive lines. Flue gas is sampled from the facility stack, the ESP/baghouse inlet, and a multi-purpose spare line. Flue gas is dried before the analyzers by a sample conditioning system which uses an ice bath to condense water from the sampled gases. In addition, a separate dedicated Perkin Elmer MCS-100 gas sampler has been recently installed at the facility. This system provides real-time in situ measurement of $\mathrm{NH}_{3}, \mathrm{HCl}, \mathrm{CO}_{2}$ and water vapor.

\section{$\underline{\text { Pollution Control Equipment }}$}

Particulate emissions are controlled by an Aeropulse pulse-jet baghouse, while sulfur dioxide emissions are controlled by an Indusco packed-column, caustic scrubber. Flue gas can be diverted by a set of valves through a pilot-scale electrostatic precipitator (ESP), which has been installed upstream from the baghouse. The ESP has a total specific collection area (SCA) of $17 \mathrm{~m}^{2} / 472$ SLPS (180 $\mathrm{ft}^{2} / 1000$ ACFM), divided into three fields, and can be used for cold-side ESP performance evaluations.

The pulse-jet baghouse and the scrubber were required for the air quality permit of the facility issued by the Jefferson County Board of Health, and therefore are always on-line. The ESP can be valved into the system before the pulse-jet baghouse to give a series ESP-baghouse combination.

Due to the complex nature of mercury chemistry, thermodynamics, and kinetics in association with chlorine and other acid gases in coal-fired boilers, a fundamental understanding of mechanisms is necessary in order to apply calcium-based sorbent technology to capture mercury. Fundamental research is normally thought of as something done on a bench-top or small scale. For mercury however, the $1 \mathrm{MW}$ (3.4 million Btu/hr) Combustion Research Facility at SRI is about as small of a coal-fired power facility as can be used to study the fundamental parameters (kinetics, flue-gas composition, and competition) relevant to Hg-speciation, capture, and chemical and physical absorption in an actual coal-fired boiler. For furnaces any smaller in size, the surface to volume ratio causes reaction mechanisms to dominate that are only minor mechanisms in a full-sized boiler. Hence, the scope of work is intrinsically both a basic fundamental research project and an applied semi-industrial scale project. The project is being pursued from a fundamental basis, the mechanistic understanding from which may be directly applied to effect and enhance mercury capture through calcium based sorbents.

\section{$\underline{\text { PSA Mercury Monitor }}$}


The mercury monitor provides real-time total and speciation measurements of mercury in the flue gas continuously from two different sample locations. It takes approximately 26 minutes for one complete cycle, from which four data points are obtained, i.e., inlet $\mathrm{Hg}^{\circ}$, inlet $\mathrm{Hg}^{\mathrm{T}}$, outlet $\mathrm{Hg}^{\circ}$, and outlet $\mathrm{Hg}^{\mathrm{T}}$. The monitor itself is a standard Sir Galahad mercury monitor, which uses a gold trap to continuously scavenge elemental mercury from a gas flow over a two minute period of time. Collection on the gold trap is necessary to obtain a mercury concentration high enough to measure. Once the gold trap has been loaded, valves are automatically switched and the gold trap heated such that the mercury is released from the gold trap and sent to the atomic florescence analyzer, where the amount of mercury released from the gold trap is measured. This total amount of mercury is divided by the amount of gas from which the mercury was collected, typically two liters, and the concentration is displayed in $\mathrm{ng} / \mathrm{L}\left(\mu \mathrm{g} / \mathrm{m}^{3}\right)$.

The most challenging part of the system is sampling and gas conditioning, particularly when sampling from a particulate laden flue gas. The PSA sampling probe from the factory is not appropriate for real flue gas sampling. However, several modifications allow successful sampling. When sampling from a relatively clean gas stream, such as after the baghouse, a disposable glass-fiber filter is used in the hot box. A glass sampling probe extends to the center of the duct, draws gas and particulate into the hot-box, just outside the duct, where the heated filter assembly removes the ash. A heated pump sends the clean sample gas through a 4.6-m (15 foot $), \sim 200{ }^{\circ} \mathrm{C}\left(\sim 390{ }^{\circ} \mathrm{F}\right)$ heated line to the gas conditioning system. The sample gas stream is divided before separately and simultaneously entering the potassium chloride and stannous chloride impingers. The potassium chloride impinger removes all oxidized (mostly $\mathrm{HgCl}_{2}$ ) mercury from the flue gas, while the stannous chloride impinger reduces the oxidized mercury to elemental mercury. Each stream of gas, representing elemental and total mercury respectively, is transported to the monitor in long $(\sim 23-\mathrm{m}(\sim 75 \mathrm{ft}))$ unheated lines, after most of the water has been condensed out by refrigeration. All four gas sampling streams representing the inlet and outlet total and elemental mercury concentrations are continuously flowing to the monitor. The monitor software decides which stream to sample and vents the other streams.

When sampling from a dirty gas stream, additional steps must be taken to prevent speciation changes and even capture of mercury through contact with a layer of ash, i.e., built up on a filter. The current strategy to remove ash interference is through use of a probe designed by Apogee Scientific, to sample gas from the duct. The Apogee probe pulls gas and particulate through an annulus at high velocity, thus scouring the surfaces of the tube clean with a highly turbulent flow. The inner tube is made of porous metal, and a small (relative to the flow through the annulus) sample of clean gas is drawn through this porous tube and sent to the gas conditioning system. For sampling either from a clean or dirty gas stream, there is a need for an advanced spike and recovery system that will spike a known amount of mercury to the inlet of the sampling device, before the filter or Apogee probe annulus. The spike and recovery system must also ensure good mixing with the flue gas before entering the probe and provide a known (small, say 5\%) fraction of the flue gas. This capability, now being developed, will provide a spike of elemental and also a spike of oxidized mercury.

\section{$\underline{\text { Electrostatic Precipitator }}$}

Although not yet operational, a four-field dry-wall electrostatic precipitator has been recently installed in the facility. With an interior that is nominally $1.4-\mathrm{m}\left(4 \frac{1}{2}{ }^{\prime}\right)$ high by $0.6-\mathrm{m}$ (2') wide by 4.9-m (16') long, the precipitator provides a maximum plate area of approximately 
$13 \mathrm{~m}^{2}$ (144 sq.ft) for an ESP sizing factor of 120 sq.ft $/ \mathrm{kacfm}$. Plate width can be changed, allowing plate spacings up to a maximum of 0.6-m (24").

Particles are charged by a rigid electrode array. The discharge electrodes are suspended from high voltage structures located in the area above the gas passage. The high voltage structures are suspended from insulators, electrically isolating them from the precipitator casing. The discharge electrodes are attached to the upper high voltage frame and extend down through the gas passages. They are aligned by the lower high voltage frame. This lower high voltage frame is suspended from the rigid discharge electrodes. The discharge electrodes are centered in the gas passages, with anti-sway mechanisms attached to the lower high voltage frame to keep it from moving in the gas stream.

As an aid to gas distribution, turning vanes, perforated plates, and baffles are used at the inlet and outlet of the precipitator chamber. The purpose is to provide uniform velocity distribution across the precipitator cross-section. Impulse gravity impact rappers are used to remove dust deposits from collecting surfaces. The rappers are located on the precipitator roof. The plunger is allowed to fall, striking the rapper bar connected to a bank of collecting surfaces within the precipitator. The resulting shock dislodges the accumulated dust. Precipitator rapping is controlled through a microprocessor-based programmable controller.

\section{$\underline{\text { Rapid Adsorption Process }}$}

Figure 2 contains a schematic of the Rapid Adsorption Process (RAP) system in oncethrough configuration, as it was used for the February tests. The flue gas from the furnace enters the bottom of the reactor and passes upward through a venturi section. At the top of the venturi section, sorbent is introduced. Two feet above this and approximately 0.1 seconds of residence time after sorbent injection, water is injected into the duct, which significantly cools the gas. The sulfur dioxide in the flue gas reacts with the sorbent. The flue gas and solids pass from the RAP to the baghouse, where virtually $100 \%$ of the solids are captured. The cleaned gas exits the baghouse to the fan and stack. The reactor was designed to provide approximately $1 \frac{1}{2}-2$ seconds reaction time before collection on the fabric filters. A second port is available at the top of the reactor, which can be used to reduce the reaction time available to approximately $3 / 4-1$ seconds. However, during the February test, this port was used to measure the temperature of the reacting flow at that location. 


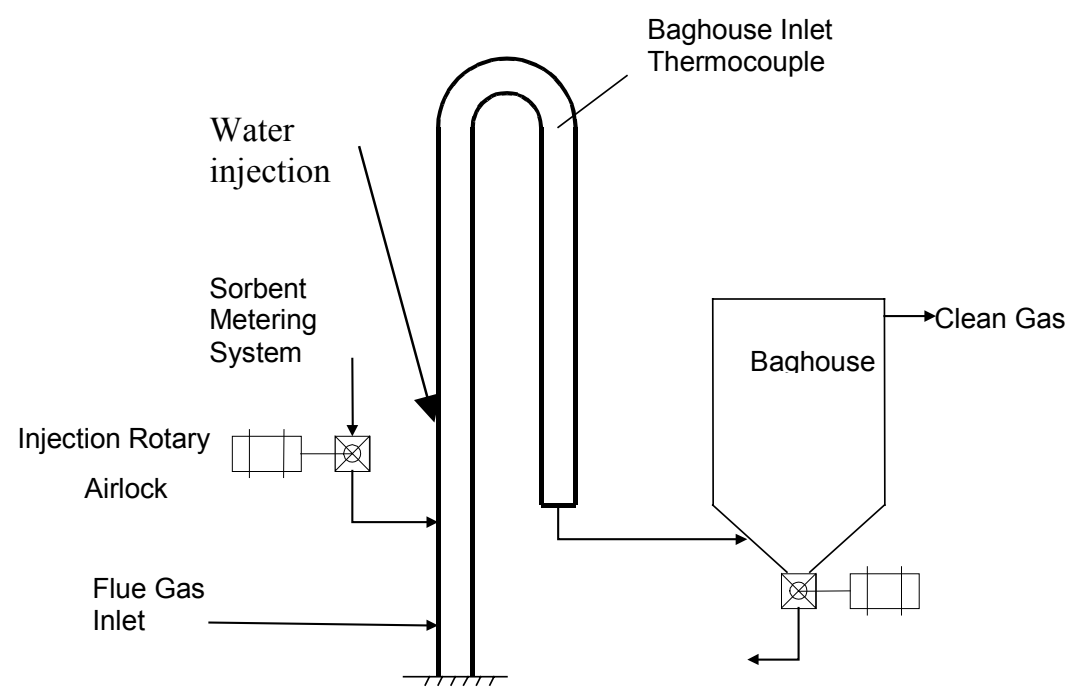

Figure 2. Schematic Flow Diagram of the Rapid Adsorption Process (RAP) (once-through).

\section{$\underline{\text { Permit Equipment }}$}

Particulate emissions are controlled by an Aeropulse pulse-jet baghouse, while sulfur dioxide emissions are controlled by an Indusco packed-column caustic scrubber. The pulse-jet baghouse and scrubber are required for the air quality permit of the facility issued by the Jefferson County Board of Health and are always on-line.

Combustor Operations

A routine facility operation is usually completed in one week, beginning at 8:00 am on Monday morning and ending at 5:00 PM on Friday afternoon. To facilitate start of testing on Monday morning the furnace is usually started on Sunday evening, firing with natural gas to heat up the system before switching to coal. It usually requires 12 hours before thermal equilibrium is achieved.

\section{Coal Type}

Table 1. Choctaw America HvA Bituminous Coal.

\begin{tabular}{|l|c|l|c|c|c|}
\hline \multicolumn{2}{|l|}{ Proximate Analysis (as rec.) } & \multicolumn{2}{l|}{ Ultimate analysis (daf) } & \multicolumn{2}{c|}{ Coal Feed Ash Analysis } \\
\hline \%Moisture & 5.01 & & $\% \mathrm{Na}_{2} \mathrm{O}$ & 0.93 \\
\%Ash & 5.65 & \%Carbon & 84.95 & $\% \mathrm{~K}_{2} \mathrm{O}$ & 2.4 \\
\%Volatiles & 34.10 & \%Hydrogen & 5.33 & $\% \mathrm{MgO}$ & 1.1 \\
\%Fixed C & 55.24 & \%Nitrogen & 1.99 & $\% \mathrm{CaO}$ & 2.23 \\
$\mathrm{HV}(\mathrm{Btu} / \mathrm{lb})$ & 13,879 & \%Sulfur & 0.95 & $\% \mathrm{Fe}_{2} \mathrm{O}_{3}$ & 14.83 \\
& & \%Oxygen & 6.78 & $\% \mathrm{Al}_{2} \mathrm{O}_{3}$ & 29.63 \\
$\mathrm{Hg}(\mu \mathrm{g} / \mathrm{g})$ & 0.13 & & & $\% \mathrm{SiO}_{2}$ & 45.73 \\
Chlorine $(\%)$ & 0.01 & & & $\% \mathrm{TiO}_{2}$ & 1.60 \\
\hline
\end{tabular}

Choctaw America, a high volatile bituminous type A coal, used for the experimental tests in December and February, was also used for the April test. Table 1 contains the ultimate, proximate and ash analyses of this coal. 


\section{$\underline{\text { Run Conditions for the February Test }}$}

The CRF furnace was configured with a single-register burner, $15 \%$ overfire air, and $3.5 \%$ furnace exit oxygen. The coal feedrate was approximately $115 \mathrm{~kg} / \mathrm{hr}(260 \mathrm{lbs} / \mathrm{hr})$, resulting in a flue gas flow rate of approximately 543 SLPS (1150 SCFM). Sorbent was injected between 5.4 and $6.8 \mathrm{~kg} / \mathrm{hr}(12$ and $15 \mathrm{lbs} / \mathrm{hr})$ into a vertical u-section of flue duct in order to allow two seconds of residence time before the sorbent collected on the bags of the fabric filter. The sorbent injection rate was chosen to obtain a stoichiometry of 1.4, sorbent to sulfur (based on the calcium in the sorbent). The actual ratios of calcium (from the sorbent) to sulfur (as $\mathrm{SO}_{2}$ in the flue gas) varied somewhat from this desired ratio. The stoichiometric ratio for the lime based sorbent was $\sim 1.5$, and that for the silica-lime based sorbent was closer to 1.0. ARCADIS had difficulty in making a sufficient quantity of the silica-lime sorbent for this test, so it was necessary to feed the sorbent at a lower feedrate in order to complete the test. Both sorbents contained $\sim 5 \%$ oxidant by weight. Hence, the oxidant concentration was in vast excess of the mercury concentration in the flue gas.

Additional moisture was injected into the furnace at a rate of $22.7 \mathrm{~kg} / \mathrm{hr}(50 \mathrm{lbs} / \mathrm{hr})$ and into the duct near the sorbent injection port at $\sim 45.4 \mathrm{~kg} / \mathrm{hr}(100 \mathrm{lbs} / \mathrm{hr})$, resulting in a flue gas moisture content after the baghouse of $\sim 7.8 \%$. During pseudo-steady-state sorbent injection, the flue gas temperature at the baghouse outlet was between 77 and $88{ }^{\circ} \mathrm{C}\left(170\right.$ and $\left.190{ }^{\circ} \mathrm{F}\right)$. The sorbent injection temperature was about $150{ }^{\circ} \mathrm{C}\left(300{ }^{\circ} \mathrm{F}\right)$ followed by water injection two feet downstream of the injection port that cooled the sorbent and flue gas down to $90{ }^{\circ} \mathrm{C}\left(195{ }^{\circ} \mathrm{F}\right)$ within 3-m (10 feet) of the water injection port.

\section{$\underline{\text { February Test Plan }}$}

Three days of testing were performed, with mercury measurements performed by both the PSA monitor and the Ontario Hydro method each day. The first day of testing was coal only. The second day, the hydrated lime + additive sorbent was tested, and the third day, the silicalime + additive was tested. By testing in this fashion, the mercury measurements could be directly compared with and without sorbent. The coal feed was continually analyzed for mercury to ensure uniformity of coal feed mercury concentration. In addition, the PSA monitor also continually measured the mercury concentrations upstream of the sorbent injection location, to ensure that the inlet conditions were unchanged from day to day. The most important aspect of the February test run was that the outlet sampling location for the PSA monitor and the Ontario Hydro measurements were performed downstream of the baghouse in a particulate free environment, thus eliminating any adverse effects of ash buildup on the filters. This was tested by frequently changing the filter on the PSA probe. No effect of replacing the filter was observed in the mercury measurements at this location.

\section{$\underline{\text { Run Conditions for the April Test }}$}

The CRF was operated in April under similar conditions as the February test. Choctaw America coal was fired at approximately $15 \mathrm{~kg} / \mathrm{hr}(260 \mathrm{lbs} / \mathrm{hr})$ into the furnace using a single register burner, $15 \%$ overfire air, and 3\% furnace exit oxygen. Mercury monitor measurements were made from the dirty flue-gas at $288^{\circ} \mathrm{C}\left(550{ }^{\circ} \mathrm{F}\right)$ and $163{ }^{\circ} \mathrm{C}\left(325^{\circ} \mathrm{F}\right)$ locations at different 
times, and mercury emissions from the baghouse exit were monitored continuously. On a dry basis, the flue gases contained the major gas concentrations shown in Table 2.

Table 2. Flue gas composition after baghouse.

\begin{tabular}{|c|c|c|c|c|c|}
\hline $\mathrm{CO}_{2}$ & $\mathrm{O}_{2}$ & $\mathrm{~N}_{2}$ & $\mathrm{NO}_{\mathrm{x}}$ & $\mathrm{SO}_{2}$ & $\mathrm{CO}$ \\
\hline $17 \%$ & $6 \%$ & $77 \%$ & $300 \mathrm{ppm}$ & $750 \mathrm{ppm}$ & $75 \mathrm{ppm}$ \\
\hline
\end{tabular}

The focus of the testing was to determine the following:

1) Test the ability of the Apogee Scientific probe to operate correctly and remove ash insitu from the flue gas while sampling.

2) Assess the ability of hydrated lime on the bags of a baghouse to capture mercury, and use these results as a baseline for evaluating the success of other sorbent technologies.

3) Validate the speciation of the mercury for the inlet conditions of the February tests.

4) Assess the ability of disperse hydrated lime to capture mercury from the flue gas, and use these results as a baseline for evaluating the success of other sorbent technologies.

5) Investigate the effect of sorbent injection temperature on the ability of hydrated lime to capture mercury both in the disperse phase and on the bags of the baghouse. In accordance with this, the hydrated lime will also be assessed for its ability to capture $\mathrm{SO}_{2}$ and mercury simultaneously when injected at the high temperature condition.

6) A demonstration of the mass balance of the mercury measurement to the coal mercury content is also presented.

Hydrated lime was injected at a rate of $6.8 \mathrm{~kg} / \mathrm{hr}(15 \mathrm{lbs} / \mathrm{hr})$, which is the same as in the February test and constitutes a stoichiometric ratio of calcium to sulfur of 1.4. Because of the extremely small concentration of mercury in the flue gas, it does not make sense to base the stoichiometry on the concentration of mercury. However, it is reasonable to base the amount of sorbent injection of the amount of sulfur in the flue gas (for a low sulfur coal). Not only is it likely that this sorbent technology will be used to capture both sulfur and mercury (for a low sulfur coal), but the ratio provides a reasonable sorbent loading for realistic application. Too much sorbent can be a solids handling, particulate capture, and disposal problem, while too little will not provide a sufficient disperse or cake substrate.

For this April test, the sorbent was collected on the bags of the permit baghouse, thus bypassing the RAP system. However, the only difference in conditions this created was to allow a straight run of duct where isokinetic sampling could be made. Isokinetic samples were taken (called mass trains) that were analyzed for mercury to provide a check on the mercury capture measurements.

\section{Results}

\section{$\underline{\text { December and January Test Results }}$}

In December, two different coals were tested, Choctaw America and Lone Mountain Bituminous coals. In January, Galatia bituminous coal was fired, which has a higher chlorine content $(\mathrm{wt} \% \mathrm{Cl}=0.28)$ than the other coals. Furnace operation of these runs was paid for by a 
biomass cofiring project. Mercury monitoring did not disturb the data collected for that project. Monitoring was performed for two main reasons. First, it was necessary to gain operational experience with the PSA monitor, including developing optimum sampling and operating configurations. As a result, SRI personnel have gained a much broader understanding of the PSA monitor and have determined the weakest parts of the system and processes that need the most attention. Also, a clear path forward is now understood to modify the system and operate the PSA monitor to obtain completely defendable data.

One of the most important needs of the monitoring system is a complete and calibrated spike and recovery system for both elemental and oxidized mercury. Such a system would allow a specified percentage of the flow with a known concentration of mercury to be injected into the flue gas in front of the filter or other particulate control device. SRI is working with PS Analytical on this effort and anticipates funding from a variety of sources to complete this project. However, no further funding from this DOE project will be required for this effort.

The spike and recovery system will allow $\mathrm{Hg}$-speciation to be investigated in a straightforward, reliable, and quantitative manner, even allowing correction of the data if needed. All other considerations of the PSA monitor, fall in the general categories of functionality, practicality, and durability or robustness.

In December, a qualification test was performed to determine if the speciation of the mercury in the CRF was similar enough to that of a full-scale boiler to allow meaningful coal speciation research to be tested. While this furnace run was part of another project, the PSA monitoring work allowed comparison to the Ontario Hydro measurements performed as part of the qualification test. Choctaw America coal was fired during this test under the same conditions as in the February and April tests. The $163{ }^{\circ} \mathrm{C}\left(325^{\circ} \mathrm{F}\right)$ sampling condition was identical to the $163{ }^{\circ} \mathrm{C}\left(325^{\circ} \mathrm{F}\right)$ sampling condition in February and April.

Figures 3 and 4 compare the PSA monitor results with the Ontario Hydro Results, both from Dec. $12^{\text {th }}$ and $13^{\text {th }}$. As shown, the elemental mercury measurements from the PSA monitor are consistent with the Ontario Hydro Measurements. Initially, or after a filter change, particulate has not built up on the filter and the elemental mercury numbers are representative of the concentration in the flue gas, in this case $>4 \mu \mathrm{g} / \mathrm{m}^{3}$. Shortly thereafter, the ash starts to build up and catalyze the elemental mercury oxidation. The slope of this decline begins to flatten around 1.5 to $2 \mu \mathrm{g} / \mathrm{m}^{3}$. The Ontario Hydro Measurements are performed for 2.5 hours without a filter change, and therefore are subject to the effects of the particulate for most of the sampling time. Consequently, the Ontario Hydro average elemental mercury values are near the bottom of the monitor derived values. This was the first time the monitor had been used at the SRI facility. There were problems with the total mercury impinger, specifically jelling that occurred due to cold temperatures. Hence, the total mercury numbers are not available from the monitor (see Figs. 3 and 4). However, the February monitor numbers for total mercury (see Figs. 5 and 6) were consistent with the December Ontario Hydro measurements at this temperature. The December test coal, furnace conditions, and sampling port conditions were the same as for the February and April tests, for this sampling port. 


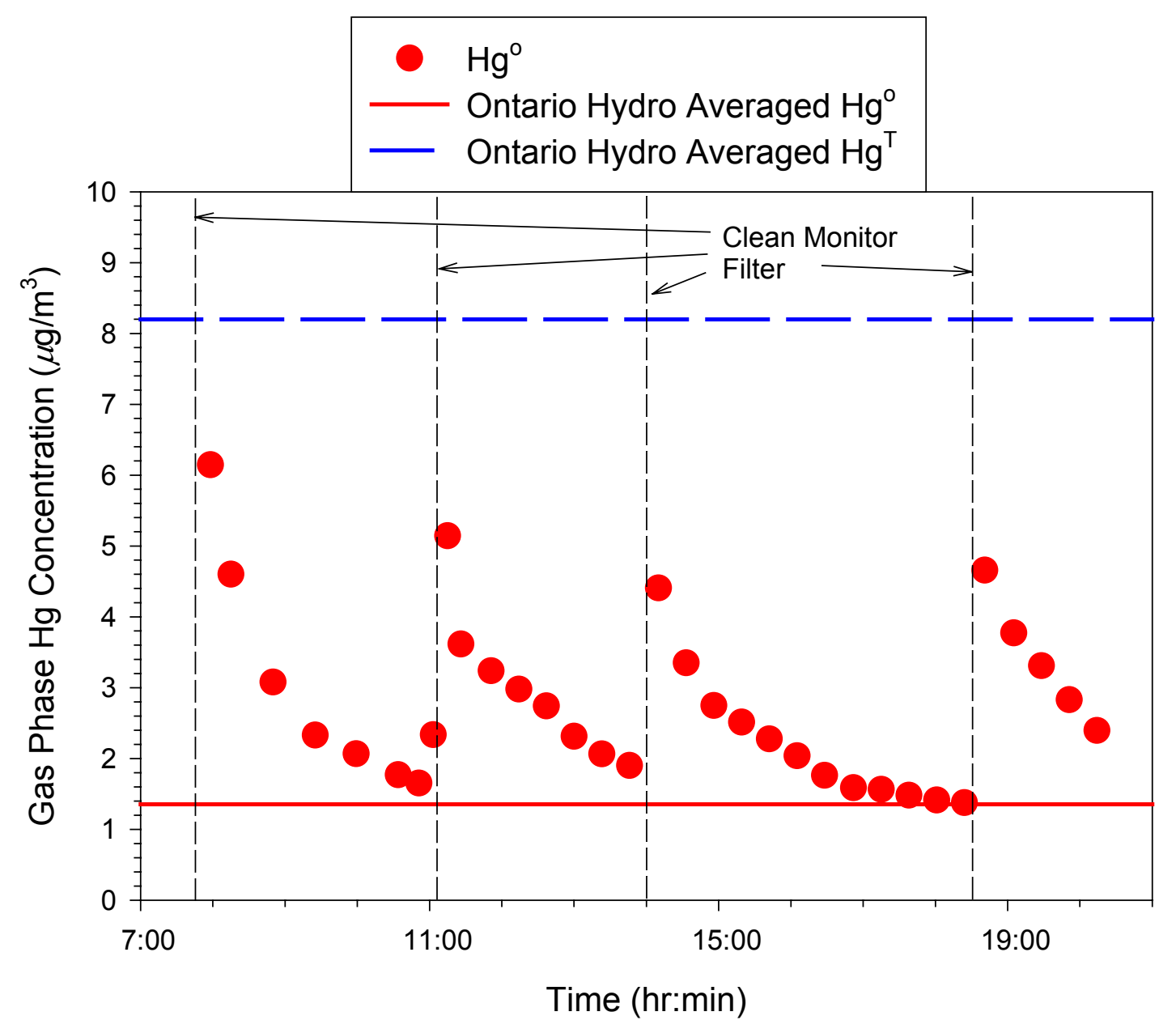

Figure 3. December $12^{\text {th }}$ qualification test results comparing Ontario Hydro measurements with PSA monitor measurements from $288^{\circ} \mathrm{C}\left(550^{\circ} \mathrm{F}\right)$ flue-gas. 


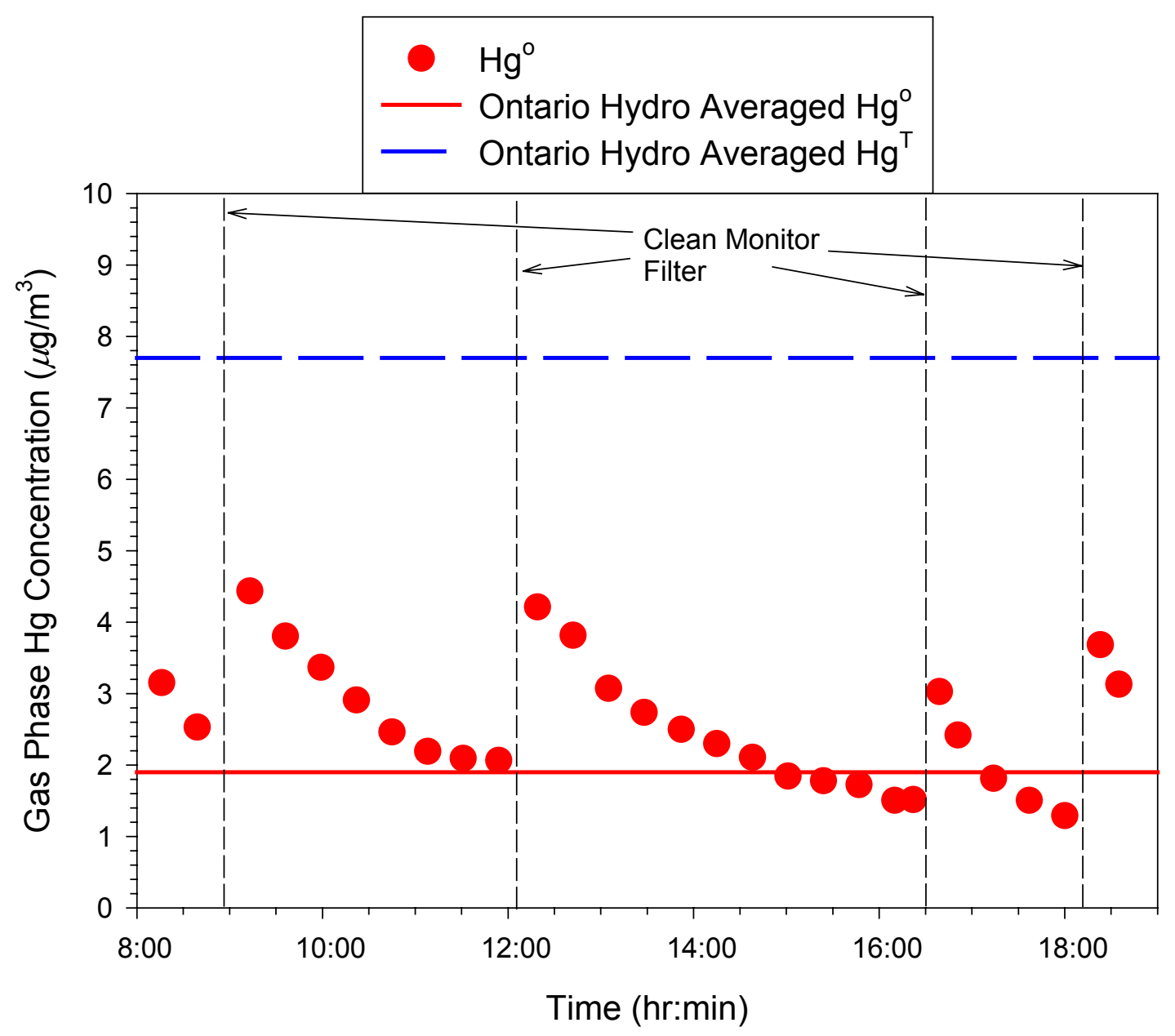

Figure 4. December $13^{\text {th }}$ qualification test results comparing Ontario Hydro measurements with PSA monitor measurements from $288^{\circ} \mathrm{C}\left(550^{\circ} \mathrm{F}\right)$ flue-gas.

\section{February Test Results}

Figures 5 and 6 compare the inlet concentrations of mercury from the coal-only day with the inlet concentrations of mercury from the lime-based sorbent day and the silica-lime-based sorbent days, respectively. There were no sorbent interactions involved at this sample port, because the sorbent was injected downstream of the inlet. As shown, the inlet concentrations of mercury were consistent between the three days, at approximately $4 \mu \mathrm{g} / \mathrm{m}^{3}$. The elemental mercury numbers were much more stable than those of total mercury. The high $\left(\sim 7 \mu \mathrm{g} / \mathrm{m}^{3}\right)$ first data point of elemental mercury after changing the filter proved to be an artifact of mercury built up in the system during a filter change. Hence, there was some uncertainty as to the actual inlet concentration of elemental mercury. The speciation at the inlet, for the February test conditions, was remeasured in April (using the PSA monitor with an APOGEE Scientific probe to remove the particulate), during the hydrated lime sorbent injection tests. The elemental mercury concentration was shown to be $\sim 4 \mathrm{~g} / \mathrm{m}^{3}$ (see Fig. 12). The total mercury concentrations were between 10 and $12 \mu \mathrm{g} / \mathrm{m}^{3}$. The oxidation of elemental mercury appeared to be catalyzed by the 


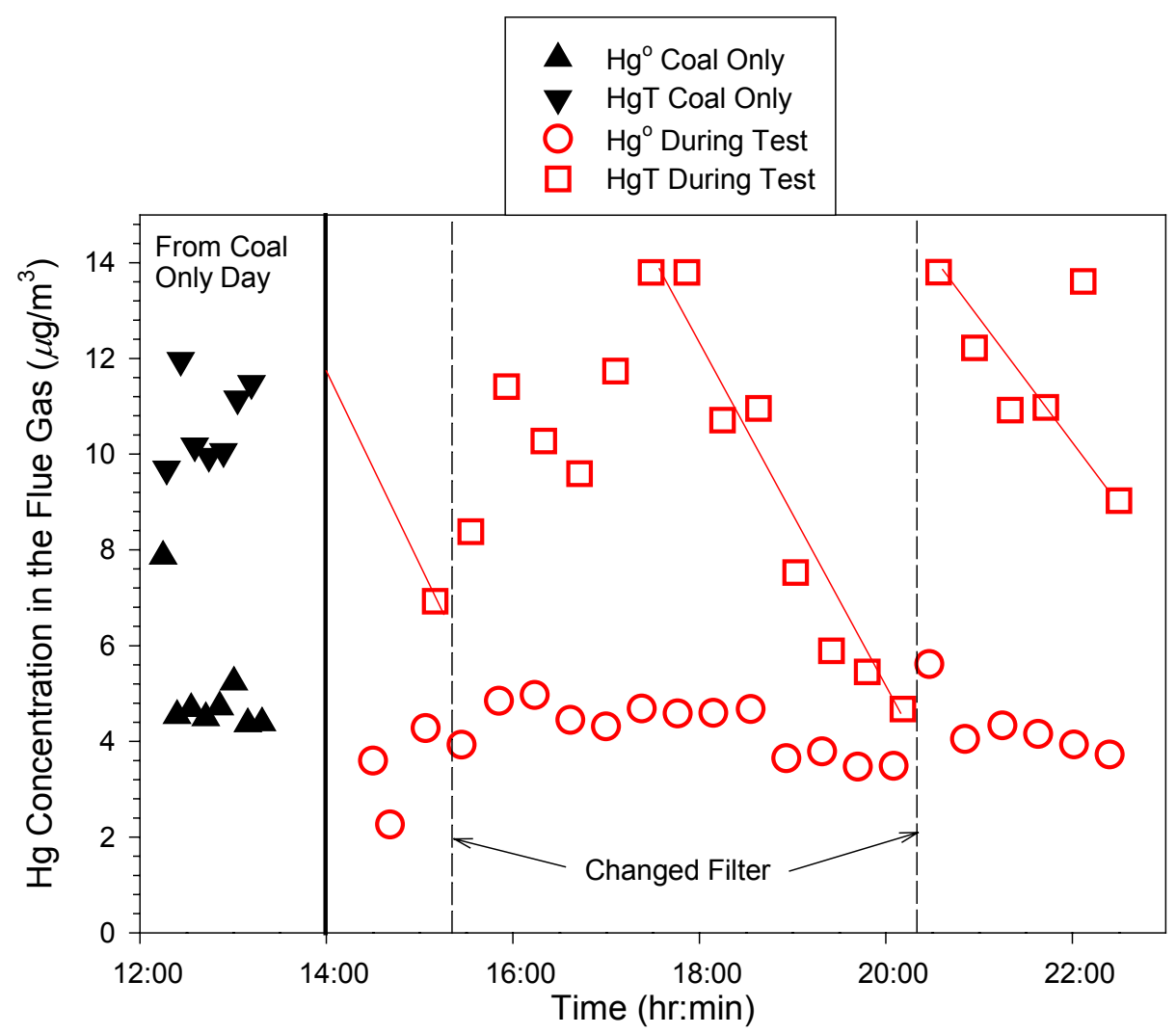

Figure 5. Inlet $\left(163{ }^{\circ} \mathrm{C}\right)$ elemental and total $\mathrm{Hg}$ concentrations from the coal-only day and the hydrated lime + additive sorbent injection day. Sorbent was injected downstream of this location.

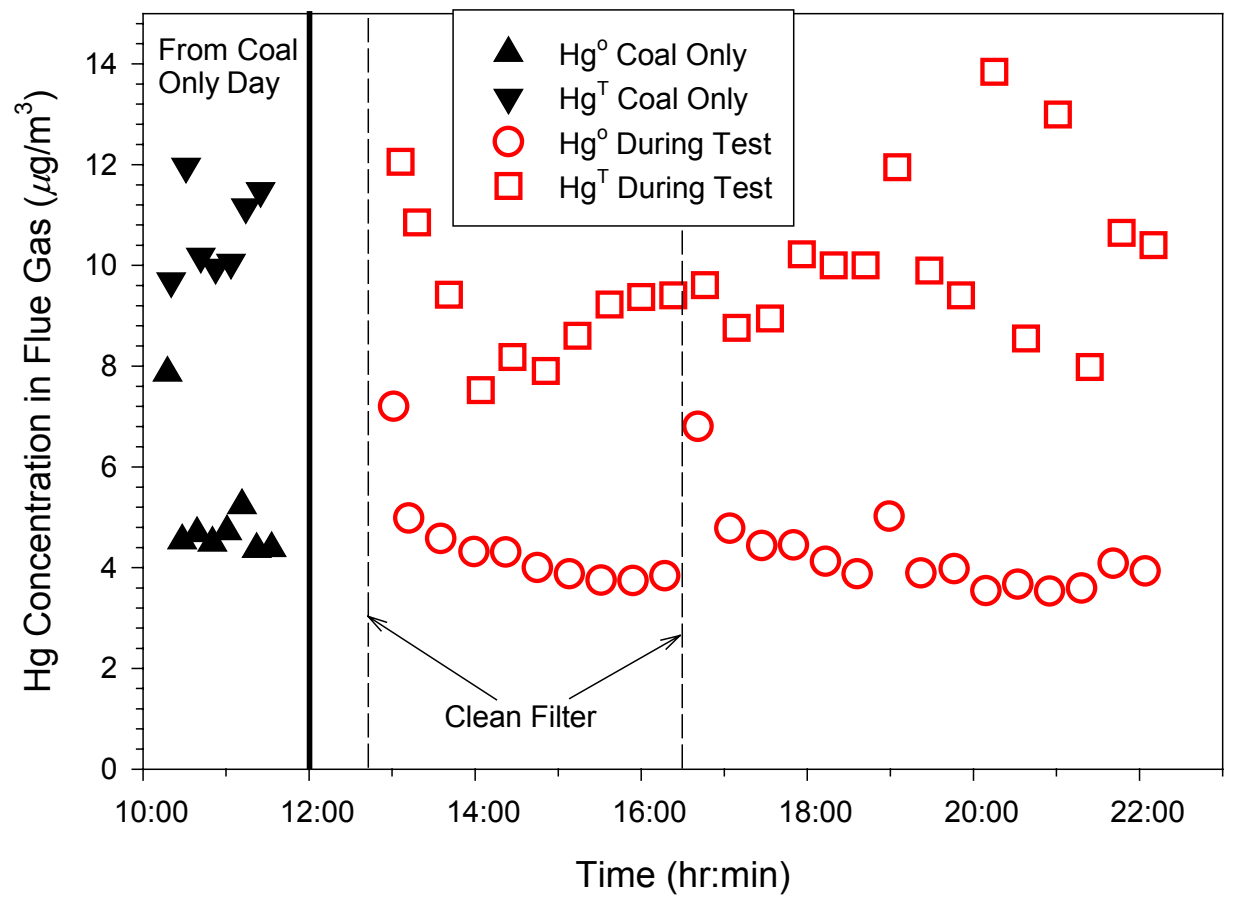

Figure 6. Inlet $\left(163{ }^{\circ} \mathrm{C}\right)$ elemental and total $\mathrm{Hg}$ concentrations from the coal-only day and the silica-lime + additive sorbent injection day. Sorbent was injected downstream of this location. 
ash on the filter, but to a lesser extent than was the case in December (see Figs. 3-6). The total mercury also appeared to be affected by particulate (see Fig. 4). This may be due to $\mathrm{Hg}$ capture by the ash on the filter. This same effect is not as distinctly observed in Fig. 5 as in Fig. 6.

As expected from observing the consistent flue gas mercury concentrations in Figs. 3-6, from the December and February test runs with Choctaw America coal, the mercury content of the coal feed was fairly consistent. Figure 7 shows the change in mercury content of the Choctaw coal being fed to the furnace over the three-day test period in February. For this investigation, coal samples were regularly taken from the coal feeder discharge. As illustrated, the standard deviation for the entire three days was only $10 \%$ of the mean value.

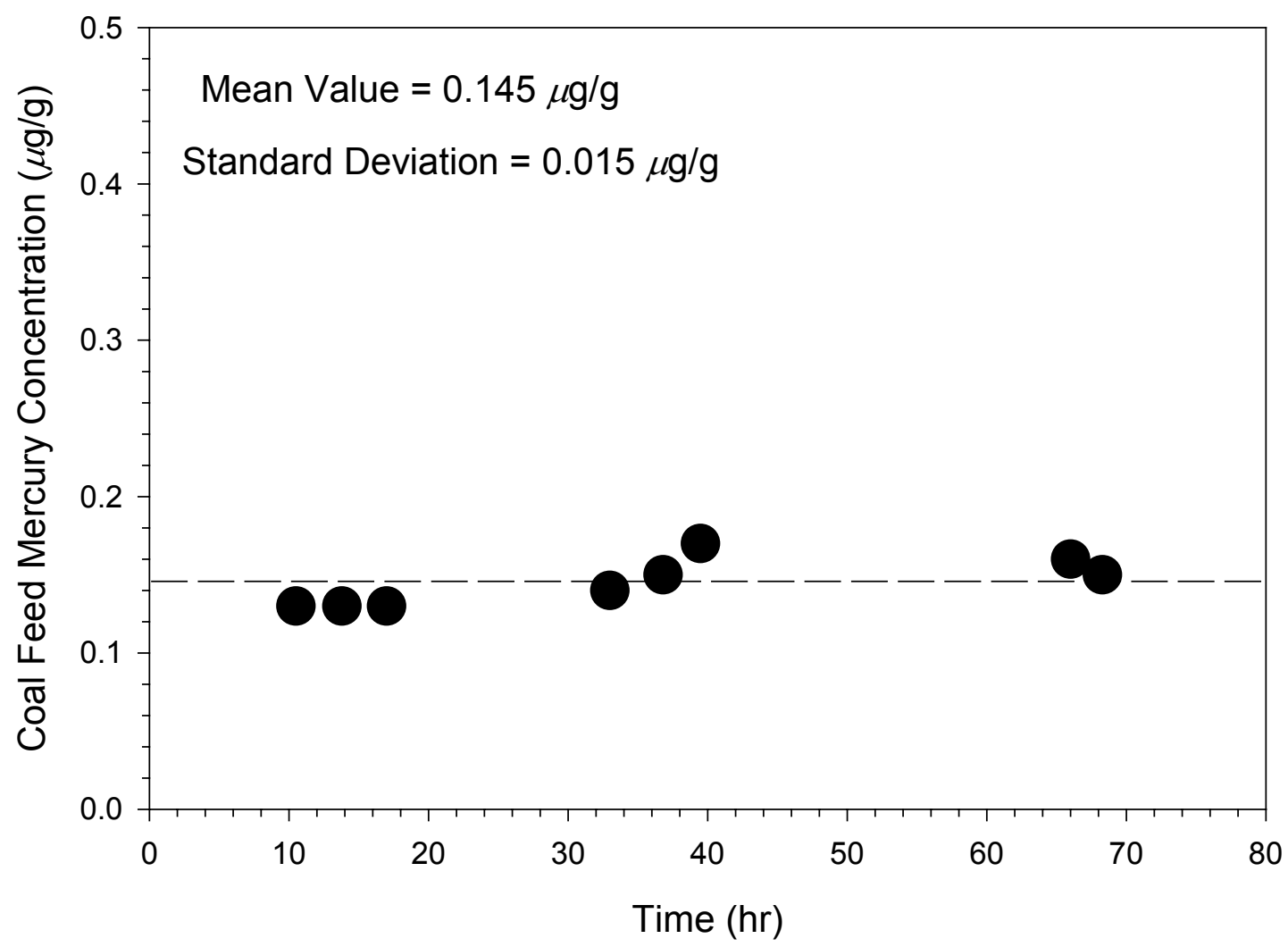

Figure 7. Variation of the coal feeder discharge mercury concentration over the three days of testing in the month of February.

Figures 8 and 9 compare the outlet concentrations of mercury from the coal-only day with those from the two sorbent test days. As mentioned earlier, these concentrations were measured after the baghouse, in a clean, particulate-free, flue gas stream. Hence, the uncertainty and interferences affecting the inlet concentration measurements were not present.

The total mercury concentration in the outlet from the coal-only day $\left(\sim 9 \mu \mathrm{g} / \mathrm{m}^{3}\right)$ was slightly less $\left(<0.5 \mu \mathrm{g} / \mathrm{m}^{3}\right.$ difference) than the inlet concentrations (see Figs. 5 and 6 ), due to air inleakage in the baghouse and water injection into the RAP tube. However, the outlet speciation (see Figs. 8 and 9) was quite different from that of the inlet (see Figs. 5 and 6). The elemental mercury concentration was only $\sim 1 \mu \mathrm{g} / \mathrm{m}^{3}$. This was due to catalysis of elemental mercury to the oxidized form as it diffused through the ash-cake in the baghouse. 


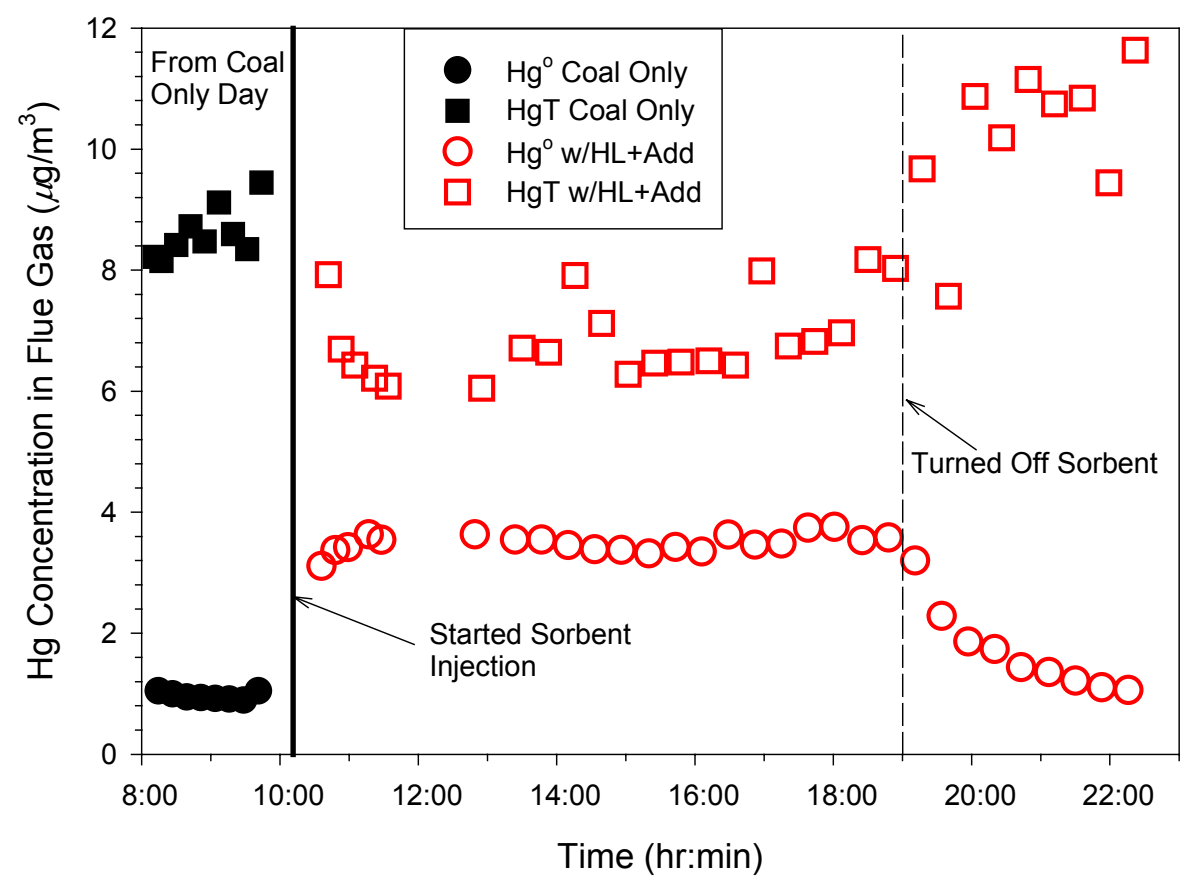

Figure 8. Outlet mercury concentrations from the PSA monitor measurements of the particulate free flue-gas after the baghouse, during hydrated lime + additive injection.

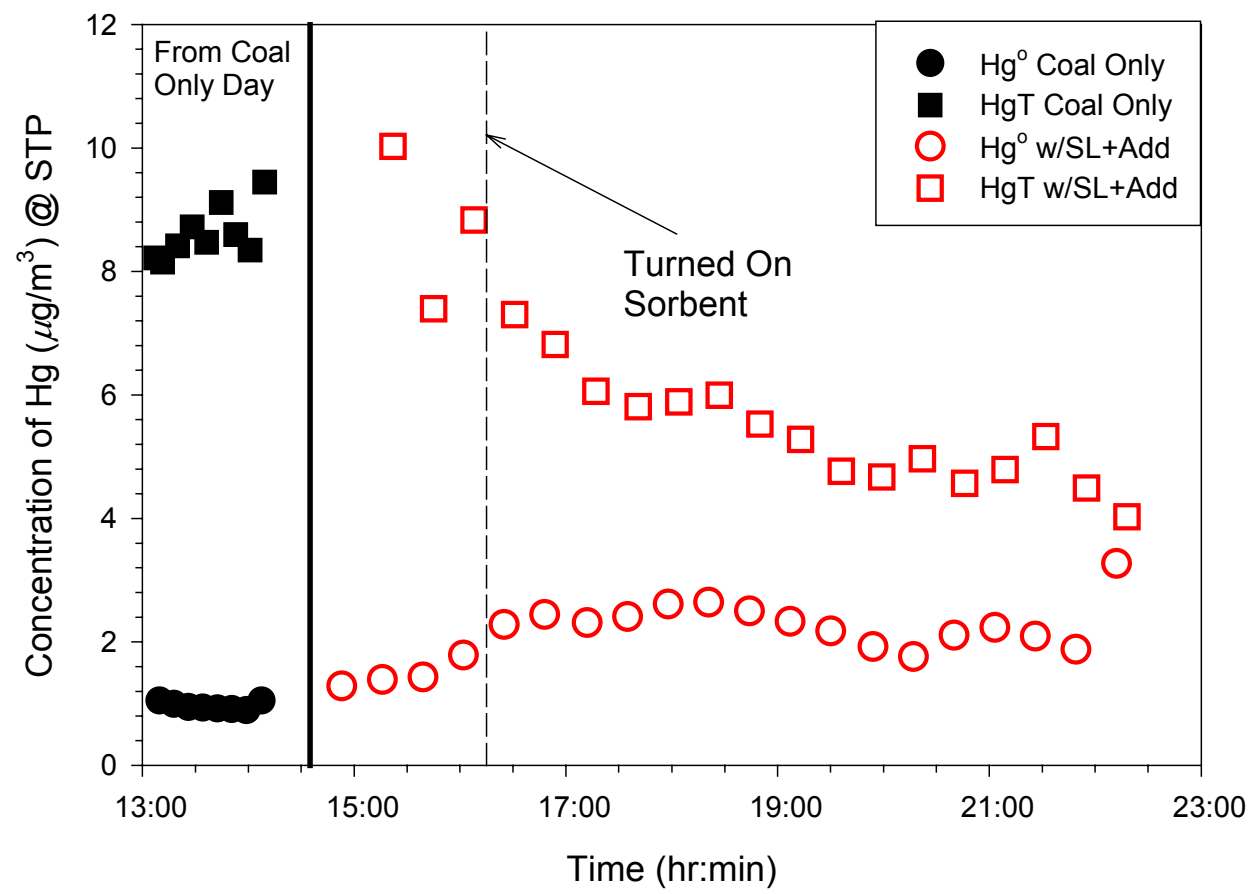

Figure 9. Outlet mercury concentrations from the PSA monitor measurements of the particulate free flue-gas after the baghouse, during silica-lime + additive injection. 
Figure 8 shows the effect of hydrated lime + additive sorbent injection. As shown, the total mercury concentration decreased during sorbent injection, indicating about $25 \%$ capture of the mercury. Unfortunately, the concentration of elemental mercury increased fourfold, perhaps back to the inlet concentration. This phenomenon could have occurred in two ways, (1) by coating the fly-ash and preventing the catalyzed oxidation of mercury across the baghouse, or (2) by reducing the oxidized mercury to the elemental form. The latter has been shown to occur with other calcium-based sorbents, whereby reducing sulfate structures form on the sorbent exterior. In either case, the results are negative for the sorbent, which was designed with an oxidant intended to oxidized the elemental mercury and thus capture both forms of mercury. These negative results were confirmed by turning off the sorbent at the time indicated on Fig. 8, with the result being that the total and elemental mercury concentrations returned to their values before sorbent injection.

Figure 9 shows similar results for the silica-lime + additive sorbent. This sorbent captured more total mercury and produced less elemental mercury than the hydrated lime + additive sorbent. However, the results show that the additive was not successful at oxidizing and capturing the elemental mercury.

With and without sorbent, the temperature of the baghouse was different, which could potentially provide different mercury oxidation kinetics. However, this difference would not be enough to explain the great and immediate change in the oxidation state of the mercury from turning the sorbent on and off. When the hydrated-lime based sorbent was turned off (see Fig. 8 ), the greatest and steepest decline in elemental mercury occurred in the first 50 minutes, during a baghouse exhaust gas temperature increase of only $17{ }^{\circ} \mathrm{C}\left(30{ }^{\circ} \mathrm{F}\right)$. The remaining decline occurred along with an additional increase in baghouse exhaust gas temperature of another $17^{\circ} \mathrm{C}$ $\left(30{ }^{\circ} \mathrm{F}\right)$.

The Ontario Hydro measurements shown in Table 3, which were only made at the cleangas outlet condition, confirm the results of the PSA monitor. They also confirm that the sorbents cause three to four times more elemental mercury to be found at the outlet than without sorbent. The sorbents-with-additives were clearly not effective at removing elemental mercury under the conditions of this test.

Table 3. Ontario hydro Hg-conc. measurements of the clean outlet gas, with standard deviations.

\begin{tabular}{|c|c|c|c|}
\hline Units $=\mu \mathrm{g} / \mathrm{m}^{3}$ & Coal Only & Hydrated Lime + Add & Silica-lime + Add \\
\hline \multirow{2}{*}{ Elemental } & $1.18+/-0.133$ & $4.92+/-0.027$ & $3.53+/-0.818$ \\
Total & $9.49+/-1.62$ & $7.34+/-0.770$ & $6.10+/-1.90$ \\
\hline
\end{tabular}

These Ontario Hydro measurements were made from flue-gas that had already been cleaned by a baghouse. Consequently, the filters had little ash on them, and were not significantly affected by particulate, which was true for the PSA monitor outlet measurements as well.

Figure 10 shows the effects of both sorbents on $\mathrm{NO}_{\mathrm{x}}$ and $\mathrm{SO}_{2}$ concentrations in the fluegas. The gas concentrations are shown at pseudo-steady state, except for the $\mathrm{SO}_{2}$ with silicalime, which is shown before and after sorbent injection. Approximately two hours was necessary for the $\mathrm{SO}_{2}$ concentrations to regain a pseudo-steady state. True steady state can only be approached at pilot and full-scale power plants. Neither the lime-based or silica-lime based 
sorbents with additives were successful at altering the $\mathrm{NO}_{\mathrm{x}}$ concentrations. Both sorbents were effective at removing $\mathrm{SO}_{2}$. The silica-lime + additive was most effective and is shown in Fig. 10 for the time before and after sorbent injection (while all other curves are for coal-only or sorbent injection only, not mixed). As shown, the addition of sorbent immediately decreased the $\mathrm{SO}_{2}$ concentrations from approximately $750 \mathrm{ppm}$ to 200 to $300 \mathrm{ppm}$.

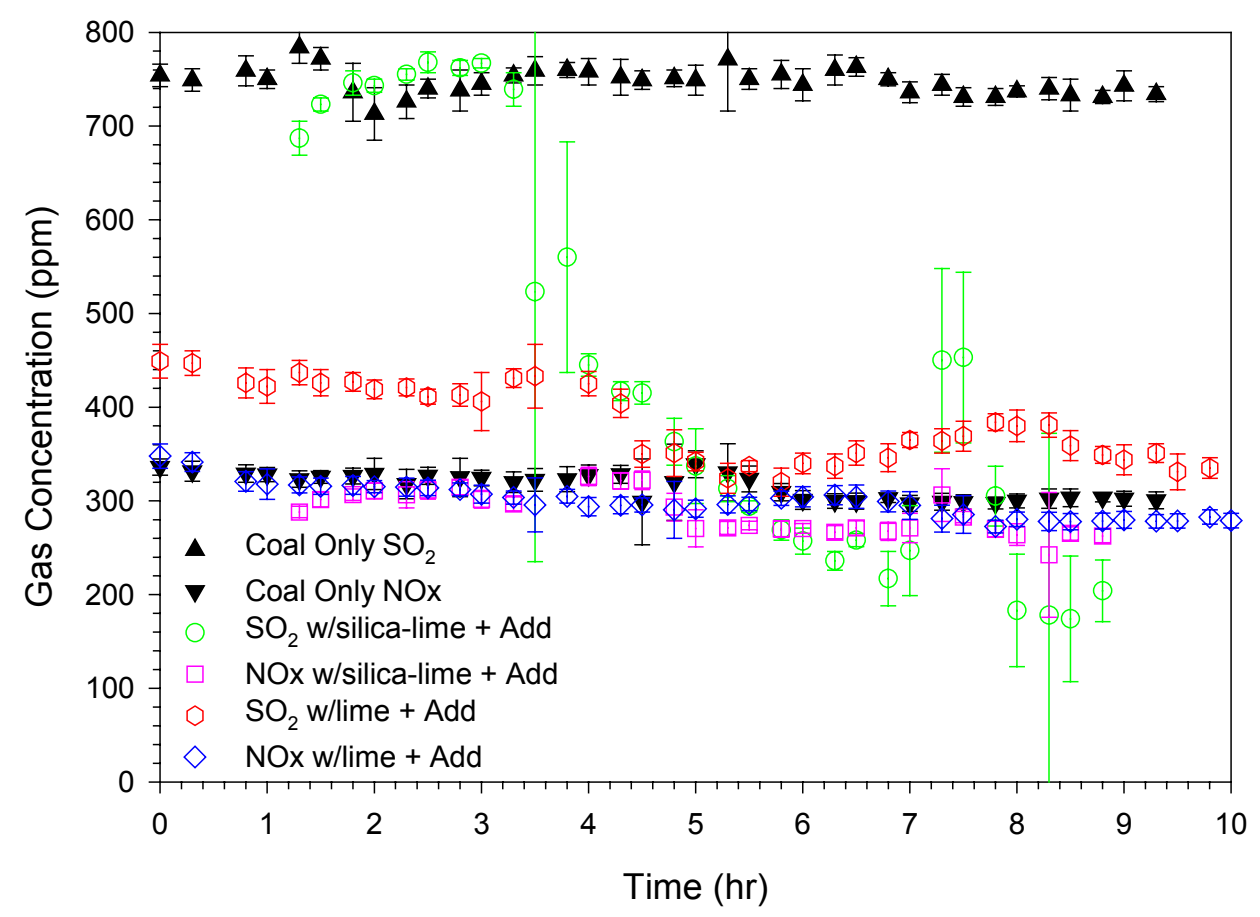

Figure 10. Effect of hydrated lime and silica-lime based sorbents on $\mathrm{SO}_{\mathrm{x}}$ and $\mathrm{NO}_{\mathrm{x}}$ flue-gas concentrations from 3 separate days of testing.

\section{$\underline{\text { April Test Results }}$}

The results will be presented according to the objectives set out in the "Run Conditions for April Tests" section of this report above.

1) Test the ability of the Apogee Scientific probe.

The Apogee Scientific probe was assembled and adapted for use with the PS Analytical system. Before this adaptation, the Apogee probe had only be in use with the Apogee Scientific monitor, not available to the public. The probe is designed to pull a large volume of flue gas from the duct through a narrow annulus, thus creating significant turbulence. A small sample of clean flue gas is pulled through the inner tube of the annulus, which is made of fine-pore sintered metal. The turbulent flow through the annulus scours the surface of the tube clean, and reinjects the particulate into the duct. The Apogee probe worked well. Steady elemental mercury measurements were obtained at or near the levels in February (initially after a clean filter was installed). The total mercury measurements were also less scattered, although still exhibited significantly more scatter than the elemental mercury measurements (see Fig. 12).

It is anticipated that the Apogee probe does allow a very thin steady state layer of ash to exist on the annulus surface. It has yet to be determined what significance this small amount of 
ash may have. A spike and recovery system being developed by SRI will allow the importance of this small, perhaps insignificant, amount of ash to be determined.

2) Assess the ability of hydrated lime on the bags.

Figure 11 illustrates the effectiveness of a hydrated lime dust cake (mixed with ash) to remove mercury from the flue gas. As shown, immediately upon injection of hydrated lime, the mercury numbers decreased rapidly. Within several hours, the hydrated lime was removing between 80 and $90 \%$ of the total mercury. As shown in Fig. 11, the mercury measurement jumped up when the baghouse was pulsed, indicating that much of the mercury capture was indeed occurring on the bags of the baghouse. When the sorbent was turned off, the mercury measurements increased. It took approximately seven hours for the total mercury measurements to return to their original values, due to sorbent retained on the bags and the time necessary to completely replace the dust cake with a cake of ash. When the sorbent was injected again, this time at a different location and temperature, the hydrated lime on the bags once again captured the mercury well. The mercury removal appeared to be heading again for 80 to $90 \%$ capture when the sorbent was turned off, and the mercury values began immediately to increase again.

The temperature of the baghouse gas was $132{ }^{\circ} \mathrm{C}\left(270{ }^{\circ} \mathrm{F}\right)$, about 27 to $38{ }^{\circ} \mathrm{C}\left(50\right.$ to $\left.65^{\circ} \mathrm{F}\right)$ hotter than the baghouse in the February test. This temperature difference was the major difference between the April and February tests, other than sorbent type. The importance of this temperature difference is being investigated on the benchscale. It is also possible that the additive in the proprietary hydrated lime base sorbent tested in February, reduced the ability of the hydrated lime to capture mercury. This latter possibility is also being investigated, from both a benchscale-experimental and a theoretical approach.

3) Validate the speciation of the mercury for the inlet.

As shown in Fig. 12, the concentration of elemental mercury at the $163{ }^{\circ} \mathrm{C}\left(325^{\circ} \mathrm{F}\right)$ sample port was approximately $4 \mu \mathrm{g} / \mathrm{m}^{3}$. This was approximately the same value as that estimated in the February test. Hence, the sorbent with oxidant tested in February was either preventing any oxidation at all from occurring on the bags, or was reducing some of the oxidized mercury to elemental mercury.

4) Assess the ability of disperse hydrated lime.

Figure 12 illustrates the ability of hydrated lime to scavenge mercury while the sorbent is dispersed in the flue gas. Two parameters are convoluted in Fig. 12, the temperature of injection and the temperature of sampling. However, this will be resolved by the results of the "mass train" measurements currently being analyzed. While sampling at the $288^{\circ} \mathrm{C}\left(550{ }^{\circ} \mathrm{F}\right)$ location, essentially no mercury capture was observed. The scatter in the total mercury measurement is significant, compared to that of the elemental mercury, and the differences in the total mercury measurement, during sorbent injection at the $1150{ }^{\circ} \mathrm{C}\left(2100{ }^{\circ} \mathrm{F}\right)$ location, are attributed to this scatter. However, while sampling at the $163{ }^{\circ} \mathrm{C}\left(325^{\circ} \mathrm{F}\right)$ location, sorbent injection at the $710{ }^{\circ} \mathrm{C}$ $\left(1310^{\circ} \mathrm{F}\right)$ location in the convection pass allowed capture of 30 to $35 \%$ of the total mercury. The residence time difference between the two sampling locations was approximately 1 second. This was certainly enough time to capture the mercury if the reaction was favorable. 


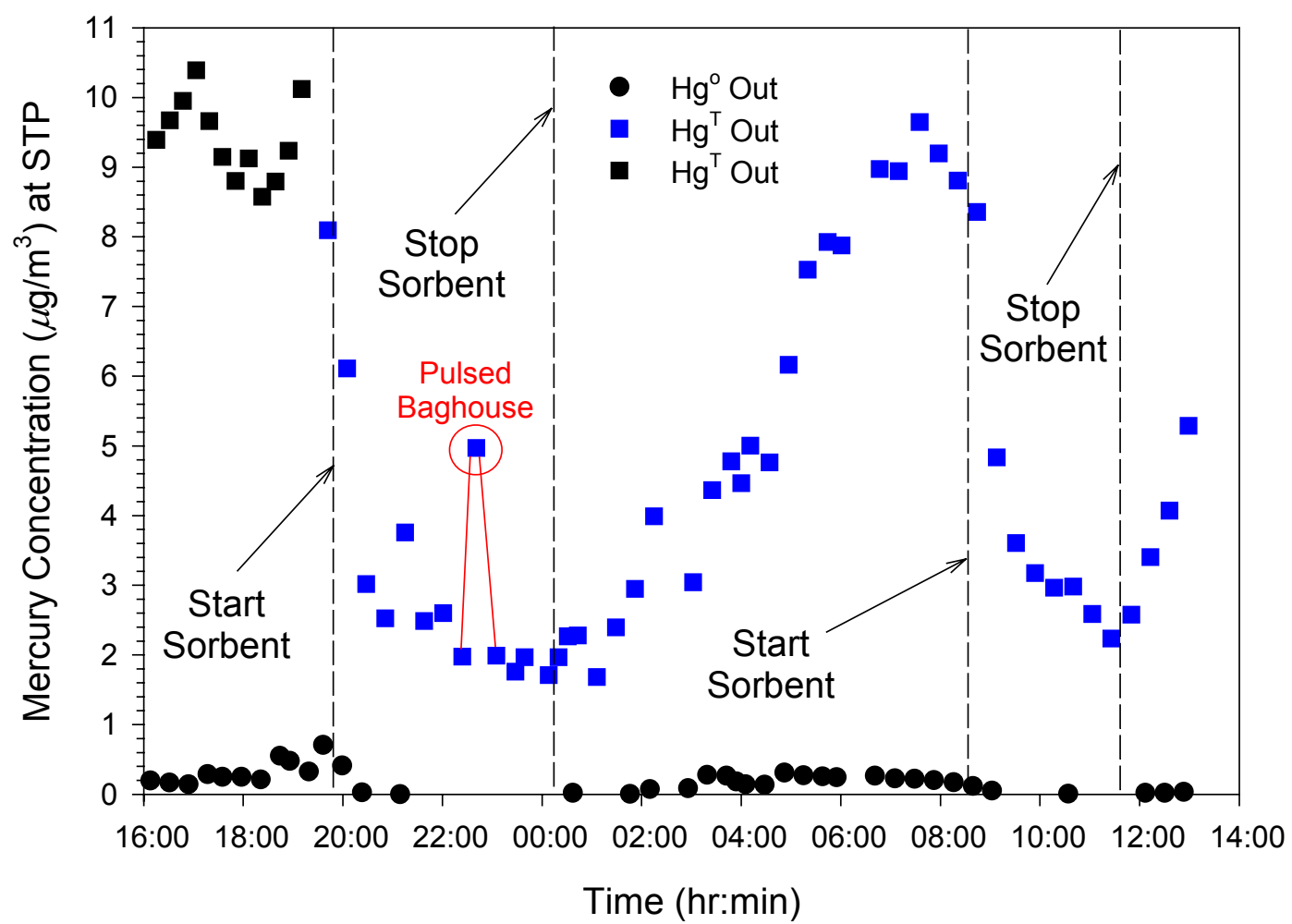

Figure 11. Mercury removal by hydrated lime in the baghouse at $132{ }^{\circ} \mathrm{C}\left(270{ }^{\circ} \mathrm{F}\right)$. The first sorbent injection location was at $1150{ }^{\circ} \mathrm{C}\left(2100{ }^{\circ} \mathrm{F}\right)$, where hydrated lime captured about 350 ppm of $\mathrm{SO}_{2}$. At the second sorbent injection location, $710{ }^{\circ} \mathrm{C}\left(1310^{\circ} \mathrm{F}\right)$, no $\mathrm{SO}_{2}$ was captured.

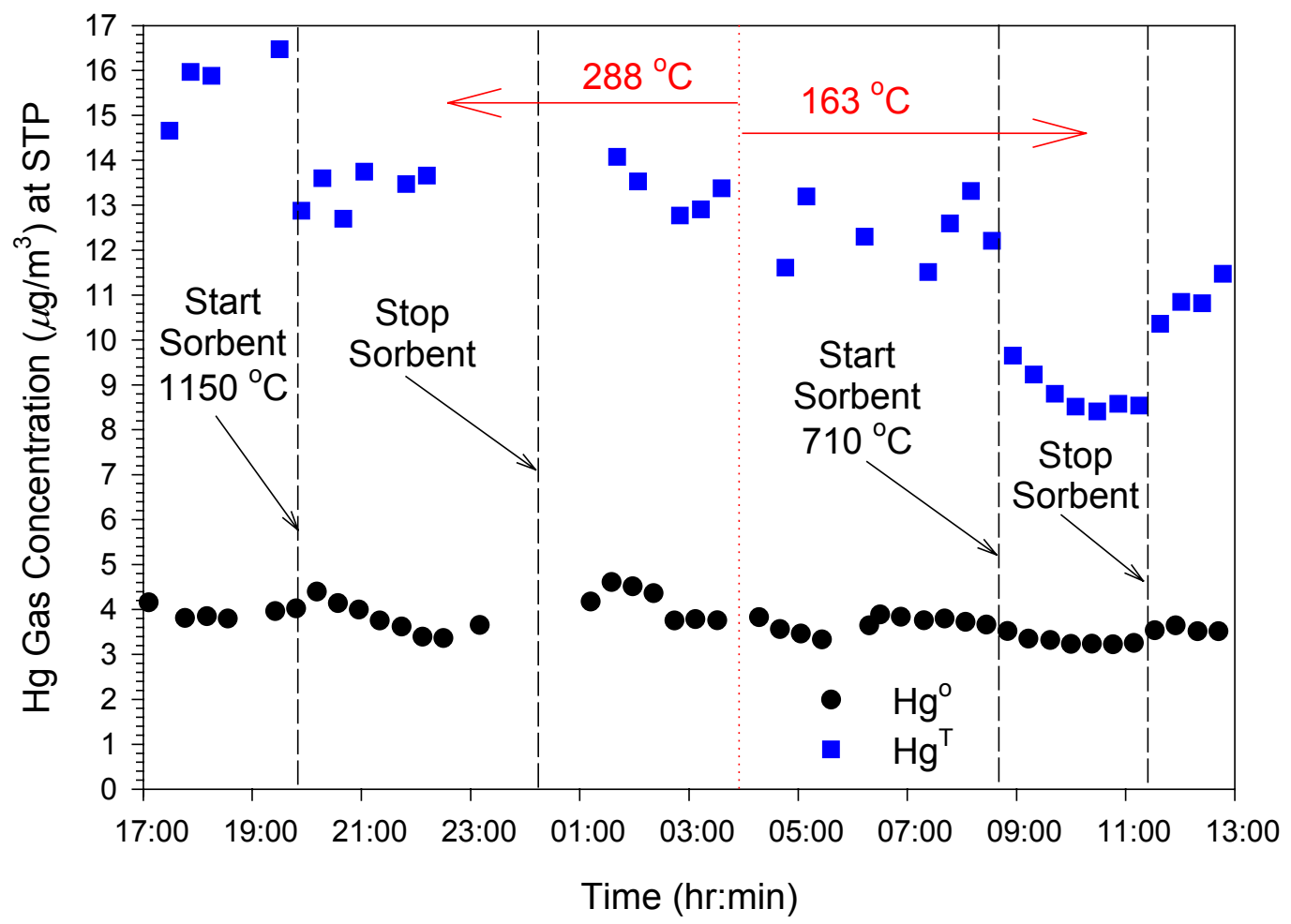

Figure 12. Mercury concentrations in the dirty flue gas, measured using the Apogee Scientific probe at the $163{ }^{\circ} \mathrm{C}\left(325^{\circ} \mathrm{F}\right)$ and $288^{\circ} \mathrm{C}\left(550{ }^{\circ} \mathrm{F}\right)$ locations. Between 30 to $35 \%$ of the mercury in the flue gas was removed by hydrated lime dispersed in the flue gas above $163{ }^{\circ} \mathrm{C}\left(325^{\circ} \mathrm{F}\right)$. 
Whether or not hydrated lime will be used to capture mercury while dispersed in the flue gas of a coal-fired boiler, these data provide a reference for testing other material. SRI will soon investigate other calcium-based sorbents with more promise for capturing mercury while dispersed in the flue gas than hydrated lime. The hydrated lime data are a good reference in terms of capture, temperature of injection, and injection rate. In addition to providing a baseline of disperse phase performance, the disperse phase removal data provide insight into the mechanisms of reaction and capture of mercury with calcium based sorbents. Specifically, an understanding of favorable temperatures of reaction were obtained, as well as rates of reaction in a realistic flue gas environment. Other parameters remain to be investigated, including coal type, speciation of mercury in the flue gas, mercury concentration, ash type, and flue gas composition. These parameters will be investigated in future tests.

5) Investigate the effect of sorbent injection temperature.

As shown in Fig. 11, the hydrated lime captured mercury equally well once on the bags of the baghouse, whether or not the sorbent was injected at the $1150{ }^{\circ} \mathrm{C}\left(2100{ }^{\circ} \mathrm{F}\right)$ or $710{ }^{\circ} \mathrm{C}$ $\left(1310^{\circ} \mathrm{F}\right)$ location. This is significant since the higher injection temperature also removed a significant amount of the $\mathrm{SO}_{2}$ from the flue gas. Sorbent injection right after the overfire air $\left(1150{ }^{\circ} \mathrm{C}\right.$ location) resulted in an immediate reduction of the $\mathrm{SO}_{2}$ from $750 \mathrm{ppm}$ to $\sim 350 \mathrm{ppm}$, measured after the baghouse. The $\mathrm{SO}_{2}$ numbers returned immediately to the original $750 \mathrm{ppm}$ value when the sorbent injection was stopped, thus indicating that no $\mathrm{SO}_{2}$ was captured on the bags. Also, when hydrated lime was injected at the $710{ }^{\circ} \mathrm{C}\left(1310{ }^{\circ} \mathrm{F}\right)$ location, no $\mathrm{SO}_{2}$ was captured either in the duct or in the baghouse.

Water injection is needed in order to capture $\mathrm{SO}_{2}$ with hydrated lime at low temperatures, such as in the RAP system. One of the parameters to be examined in the future is the ability of hydrated lime to capture mercury and $\mathrm{SO}_{2}$ at low temperatures, such as in the RAP system with water and perhaps slurry injection.

As discussed above, Fig. 12 shows the lack of capture before the $288^{\circ} \mathrm{C}\left(550{ }^{\circ} \mathrm{F}\right)$ location, when injecting hydrated lime at $1150{ }^{\circ} \mathrm{C}\left(2100{ }^{\circ} \mathrm{F}\right)$, and the capture of 30 to $35 \%$ mercury before the $163{ }^{\circ} \mathrm{C}\left(325^{\circ} \mathrm{F}\right)$ location, when injecting at $710{ }^{\circ} \mathrm{C}\left(1310^{\circ} \mathrm{F}\right)$. There are two distinct ways in which the injection temperature difference could affect the ability of the sorbent to capture mercury. First, significant capture of $\mathrm{SO}_{2}$ occurred, following sorbent injection at the $1150^{\circ} \mathrm{C}\left(2100^{\circ} \mathrm{F}\right)$ location. This chemical change of the sorbent through the capture of sulfur may have had an effect on mercury capture. Also, the intensity of the flash-calcination (driving off the moisture rapidly) is much greater at the higher temperature, which can have a significant impact on the internal surface area of the hydrated lime sorbent particles. It is also possible that the temperature of injection had no effect on mercury capture whatsoever, and the difference in the mercury removal (shown in Fig. 12) was entirely due to the different sampling locations (288 ${ }^{\circ} \mathrm{C}$ as opposed to $163{ }^{\circ} \mathrm{C}$ ). If this is true, it would prove that 30 to $35 \%$ of the mercury was captured by disperse hydrated lime during a residence time of one second, in a temperature range between 163 and $288^{\circ} \mathrm{C}\left(325\right.$ and $\left.550{ }^{\circ} \mathrm{F}\right)$.

The answer to this mystery will be elucidated once the lab results are returned on the analysis of the "mass train" samples taken during each of the sorbent injection tests. If the sorbent injection temperature had an impact on the capture of mercury by sorbent dispersed in the flue gas, then the concentration of mercury in each sample should be different. 
6) A demonstration of the mass balance.

Per the specific request of DOE, a comparison of the monitor measurements with a mass balance of mercury in the coal is presented in Fig. 13. As illustrated, the mercury monitor measurements are consistent with the mass balance. In general however, there may be furnace surface parameters that alter the mercury content to be either higher or lower than that predicted by a mass balance. As part of another research project at SRI, these parameters will be investigated in the coming year.

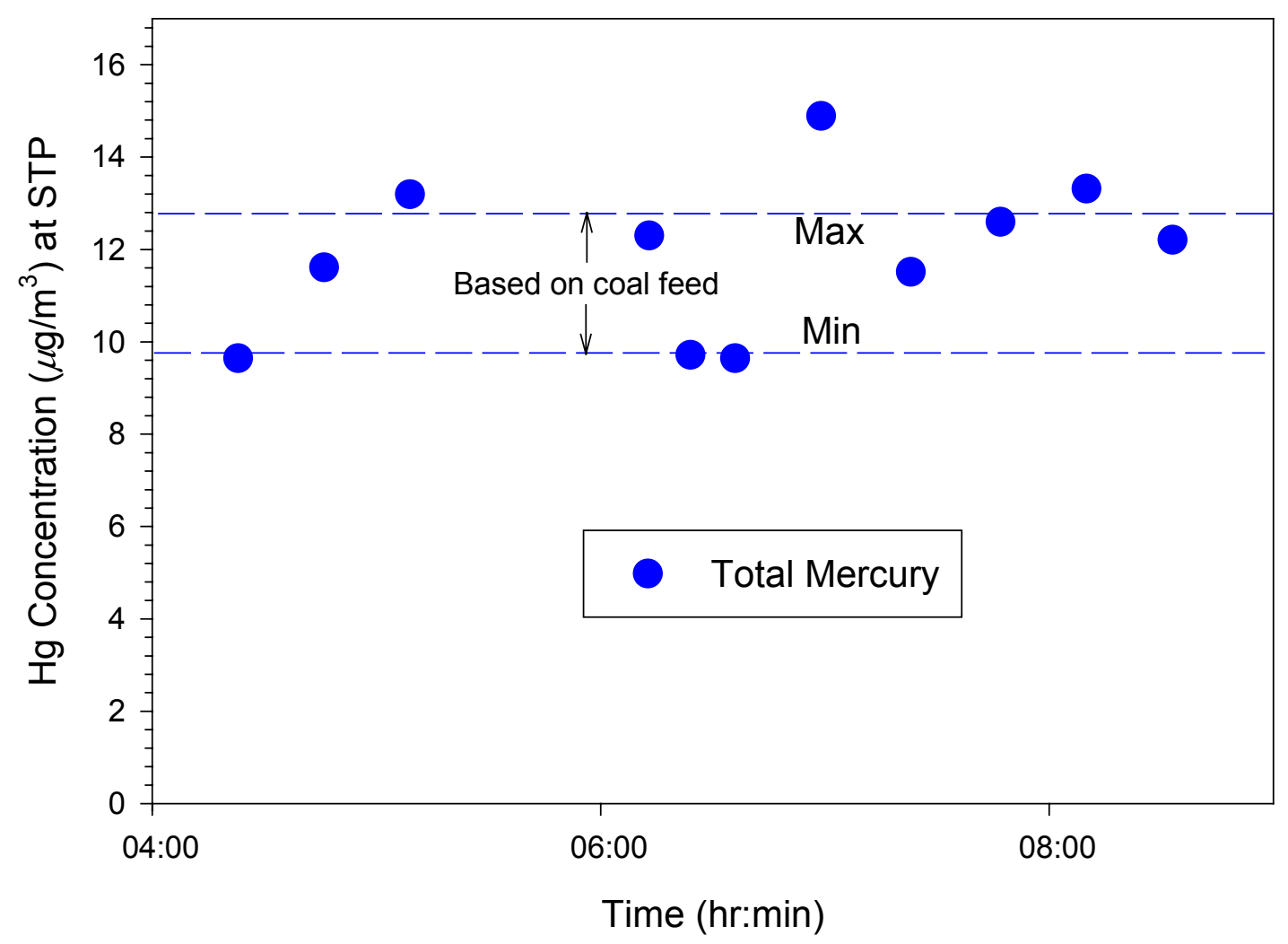

Figure 13. This illustrates the agreement of the mercury monitor measurements at the $163{ }^{\circ} \mathrm{C}$ $\left(325^{\circ} \mathrm{F}\right)$ location with the mercury concentration predictions, based on a mass balance of mercury from the coal feed (Choctaw America Coal).

\section{Discussion}

The investment of the initial funding of this DOE project by SRI in developing mercury measurement capabilities has paid off. The originally anticipated rate of data collection was one data point per day. Now, due to the technology and capabilities obtained, SRI will be able to obtain at least three times as much data as originally anticipated, for future years of the project.

The following discussion relates to Focus Area 1 of the Scope of Work only:

The desired effect of adding an oxidant to the sorbent is to either directly oxidize the mercury to $\mathrm{HgCl}_{2}$ or to form other gases, such as $\mathrm{H}_{2} \mathrm{SO}_{4}$, which will in turn contribute to mercury oxidation. The mercury in the oxidized form would then be more easily captured by 
calcium or would more easily condense into the pores of the sorbent. In any case, the reactivity of the oxidant in the flue-gas is an important parameter. The bench-scale work on these sorbents involved capturing mercury in a fixed-bed reactor while passing a calibrated amount of mercury over the bed of sorbent along with moisture and $\mathrm{CO}_{2}, \mathrm{O}_{2}$, and $\mathrm{SO}_{2}$ gases. The presence of $\mathrm{SO}_{2}$ gas enhanced mercury capture, hence the theory of $\mathrm{SO}_{3}$ (actually $\mathrm{H}_{2} \mathrm{SO}_{4}$ ) formation as an important step in the process.

The sorbent test conditions in the CRF were somewhat similar to those of the packed bed, specifically in the baghouse where the sorbent formed a cake layer through which the flue-gas flowed. However, the sorbent also experienced a two-second disperse phase residence time before entering the baghouse. These two seconds were provided in an attempt to increase the sorbent effectiveness by increasing the contact time with the flue-gas and allow mixing of sorbent and flyash, such that an even and proper dustcake would form on the bag surfaces. However, due to the different transport characteristics of the disperse phase, this time may have been spent deactivating the sorbent additive. Nevertheless, two seconds was unlikely enough time to completely deactivate the sorbent additive.

The main differences between the CRF and the benchscale conditions were (1) the presence of flyash and (2) the gas composition. The CRF had about $350 \mathrm{ppm}$ of $\mathrm{NO}_{\mathrm{x}}$ and 75 ppm of CO present at all times, while neither gases were introduced in the bench-scale experiments during mercury measurements. These highly reactive gases may have competed for reaction with the oxidant itself or with the $\mathrm{H}_{2} \mathrm{SO}_{4}$ formed from the reaction of $\mathrm{SO}_{2}$ with the oxidant. If so, the mercury in such small concentrations would likely not have been able to compete successfully with these large-quantity gases, particularly since this is a process limited by residence time. In addition, the oxidants may have been adversely affected by the sorbent injection temperature in the CRF. The temperature of the benchscale tests were at $80{ }^{\circ} \mathrm{C}$ and $100^{\circ} \mathrm{C}\left(176^{\circ} \mathrm{F}\right.$ and $\left.212^{\circ} \mathrm{F}\right)$. The temperature of the bags in the pilot-scale tests was approximately the same $\left(77\right.$ to $\left.88^{\circ} \mathrm{C}\right)$. However, sorbent was injected into the RAP tube at 150 ${ }^{\circ} \mathrm{C}\left(300{ }^{\circ} \mathrm{F}\right)$. Although quickly cooled to below $90{ }^{\circ} \mathrm{C}\left(195^{\circ} \mathrm{F}\right)$, the initial temperature may have altered the sorbent.

While the ARCADIS proprietary sorbents were unsuccessful under the duct injection conditions of the February test, they may work at cooler injection temperatures with less $\mathrm{SO}_{2}$ present. By injecting these sorbents at the top of the RAP tube, while using the RAP with recycle, a much cooler injection temperature would be provided, with much less deleterious $\mathrm{SO}_{2}$ present.

\section{Future Work}

Future testing plans currently fall into three categories, (1) benchscale work, (2) pilotscale experiments for the remainder of this fiscal year, ending in September 2002, and (3) pilotscale experiments for future years of the project.

\section{1) Benchscale work}

The following test plan attempts to resolve some of the remaining questions with respect to the proprietary sorbents produced by ARCADIS G\&M. One of the primary questions to resolve is whether a sorbent/fly ash interaction exists that results in an increase in elemental mercury concentration, either by preventing oxidation or reducing oxidized mercury on the bags. 
This test plan also attempts to answer whether there is a significant interaction of the sorbent + additive with other flue gas components preventing the oxidation and control of elemental mercury. Further investigations may build on this matrix to investigate other aspects of interest such as intermediate temperature conditions, level of $\mathrm{SO}_{2}$ and oxygen, and testing of hydrated lime.

The benchscale test matrix is illustrated in Table 4 . The test matrix is a factorial design on three parameters: fly ash, sorbent, and temperature. Tests 1-8 are the saturated factorial design. Tests 9-12 are a replicate of the half fraction containing high fly ash levels. Replicate tests are necessary because there are plausible two and three factor interactions. Tests 13 and 14 complete a two-factor factorial matrix with tests 3 and 7 , with respect to reaction temperature and $\mathrm{NO}$ and $\mathrm{CO}$ concentrations. All 14 tests are randomized (no blocking), resulting in four degrees of freedom. The error estimate from the 3-parameter factorial will be used in the analysis of the 2-parameter factorial as well. Factorial analysis will proceed via the customary $\mathrm{F}$ test procedure using $95 \%$ confidence ( $5 \% \alpha$ risk). At this time, only elemental mercury emission results will be incorporated into the analysis.

Table 4. Benchscale Test Plan Matrix

\begin{tabular}{|l|l|l|l|l|l|}
\hline Test \# & Run Order & Fly Ash & Sorbent & Temperature & NO/CO \\
\hline 1 & 12 & - & - & - & + \\
\hline 2 & 2 & + & - & - & + \\
\hline 3 & 6 & - & + & - & + \\
\hline 4 & 3 & + & + & - & + \\
\hline 5 & 8 & - & - & + & + \\
\hline 6 & 4 & + & - & + & + \\
\hline 7 & 13 & - & + & + & + \\
\hline 8 & 5 & + & + & + & + \\
\hline 9 & 14 & + & + & + & + \\
\hline 10 & 10 & + & - & + & + \\
\hline 11 & 11 & + & + & - & + \\
\hline 12 & 1 & + & - & - & + \\
\hline 13 & 9 & - & + & + & - \\
\hline 14 & 7 & - & + & - & - \\
\hline
\end{tabular}

Testing will be performed in a sand-bed reactor. Simulated flue gas will pass through the sand-bed in downward flow configuration to ensure a packed bed. Breakthrough of elemental mercury will be monitored with a UV analyzer and integrated as discrete trapezoids. Mercury concentrations will be corrected for $\mathrm{SO}_{2}$ interference using a linear response. Elemental Mercury will be generated by a permeation device swept by nitrogen to deliver a known mass rate. Humidity will be generated by evaporating water. While the final humidification scheme may vary depending on the flow rates required, it is anticipated to incorporate metered water injection into an evaporation chamber to produce $7.8 \% \mathrm{H}_{2} \mathrm{O}$. Remaining simulated flue gas compounds will be delivered through mass flow controllers. The target concentrations on a dry basis are $9 \%$ $\mathrm{O}_{2}, 16 \% \mathrm{CO}_{2}, 750 \mathrm{ppm} \mathrm{SO}, 350 \mathrm{ppm} \mathrm{NOx}$, and $75 \mathrm{ppm} \mathrm{CO}$. The final elemental mercury concentration may vary depending on the flow and the permeation device parameters, which may change during construction and shakedown. Shakedown tests will also ensure that a measurable 
conversion of elemental mercury with fly ash can be observed at proposed test conditions, since fly ash has shown significant conversion of elemental mercury in the SRI pilot system.

The $-/+$ values of the parameters evaluated are given in Table 5.

Table 5. - /+ values of the parameters for the test matrix in Table 4.

\begin{tabular}{|c|c|c|c|c|}
\hline Parameter & Temperature & Fly Ash* & Sorbent* & NO/CO \\
\hline+ & $140{ }^{\circ} \mathrm{C}$ & present & present & $350 \mathrm{ppm} / 75 \mathrm{ppm}$ \\
\hline- & $80{ }^{\circ} \mathrm{C}$ & not present & not present & none \\
\hline
\end{tabular}

* When flyash and sorbent are present together, sorbent will compose $36 \mathrm{wt} \%$ of the mixture. This is the $\mathrm{wt} \%$ of sorbent collected on the bags in the pilot-scale tests.

Based on the findings from this test matrix, other benchscale experiments will likely be performed. Specifically, a more detailed test of temperature will follow any significant temperature effect observed, and apparent success or failure of the hydrated lime + additive sorbent will be validated by comparison with unblemished hydrated lime.

\section{2) Pilot-scale experiments - Fiscal Year 2002}

All of the tests described in this section can and will be accomplished (this FY), with the remaining funds DOE is to provide this fiscal year (FY2002). Table 6 contains a list of experiments to be performed in the CRF this fiscal year. The actual matrix may be adjusted based on findings obtained from other tests in the CRF (funded by other projects) or based on the initial results from the test matrix itself.

Table 6. Remaining FY 2002 Pilot Scale Experiments.

\begin{tabular}{|c|c|c|c|c|}
\hline Parameters & \multicolumn{4}{|c|}{ Days } \\
\hline Sorbents & 1 & 2 & 3 & 4 \\
\hline \multirow{3}{*}{$\begin{array}{c}\text { Kaolinite } \\
\text { Kaolinite mixed with Hydrated Lime } \\
\text { Hydrated Lime } \\
\end{array}$} & $\bar{X}$ & & & \\
\hline & & $\mathrm{X}$ & & \\
\hline & & & $\mathrm{X}$ & $\mathrm{X}$ \\
\hline \multicolumn{5}{|l|}{ Location of Mercury Capture } \\
\hline \multirow{3}{*}{$\begin{array}{c}\text { Disperse Phase } \\
\text { On Bags of Baghouse } \\
\text { RAP with Recycle } \\
\end{array}$} & $\bar{X}$ & $\bar{X}$ & & \\
\hline & $\mathrm{X}$ & $\mathrm{X}$ & & \\
\hline & & & $\mathrm{X}$ & $\mathrm{X}$ \\
\hline \multicolumn{5}{|l|}{ Temperatures of Injection } \\
\hline \multirow{2}{*}{$\begin{array}{l}\text { Sorbent Injection } \\
\text { Oxidant Injection }\end{array}$} & $\mathrm{H}, \mathrm{M}$ & $\mathrm{H}, \mathrm{M}$ & $\mathrm{L}$ & $\mathrm{L}$ \\
\hline & & $\mathrm{M}$ & & $\mathrm{L}$ \\
\hline
\end{tabular}

Note: $\mathrm{H}=\operatorname{High}\left(900\right.$ to $\left.1200{ }^{\circ} \mathrm{C}\right), \mathrm{M}=\operatorname{Medium}\left(130\right.$ to $\left.800{ }^{\circ} \mathrm{C}\right), \mathrm{L}=\operatorname{Low}\left(\sim 80\right.$ to $\left.100{ }^{\circ} \mathrm{C}\right)$.

The matrix of experiments shown in Table 6 will provide a minimum of 12 data points, an average of 3 data points per day. This is a three-fold increase in data over the estimate originally provided for this project. This ability to obtain more data per day is a result of the capabilities SRI has obtained through the development efforts of the first part of this project. 
The ability of kaolinite to sorb mercury will be investigated in the same way as hydrated lime in the April test. Mixtures of kaolinite and hydrated lime will also be investigated.

Kaolinite and mixtures of kaolinite and hydrated lime have a greater potential to capture mercury while the sorbent is dispersed in the flue gas, than does hydrated lime. The potential of forming stable, non-leachable, and thermally stable products is also much higher than with hydrated lime sorbent by itself. In addition to testing injection of these sorbents in the disperse phase, their potential to capture mercury on the bags of the baghouse will also be examined. A third parameter to be investigated is the injection of an oxidant (such as calcium hypochlorate) with and without the injection of hydrated lime and kaolinite mixtures.

Low-temperature simultaneous capture of $\mathrm{SO}_{2}$ and mercury will be investigated by operating the RAP system with recycle, using hydrated lime as a sorbent. These tests can be performed fairly quickly after the RAP system has come to steady state, but there are typically delays associated with trouble shooting the operation of the RAP system. Oxidant injection will also be tested in the RAP system with recycle, either with an ARCADIS sorbent or through direct oxidant injection. The oxidant injection strategy employed for the test will depend partly on the results of the ARCADIS benchscale tests currently underway.

\section{3) Pilot-scale experiments for future years}

Tables 7 and 8 contain experiments to be performed in the CRF in future years of this project. The actual matrix may be adjusted based on findings obtained from other tests in the CRF (some of which are funded by other projects) or based on the initial results from the test matrix itself.

Table 7. Parameters to be tested in the Year 2 matrix.

\begin{tabular}{|c|c|c|c|}
\hline \multicolumn{2}{|r|}{ Coal Type } & \multicolumn{2}{|r|}{ Spiking and Flame Variations (SFV) } \\
\hline 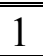 & Choctaw America HvA Bituminous & 1 & Low $\mathrm{NO}_{\mathrm{x}}$ furnace operation \\
\hline 2 & Jacobs Ranch $\left(\right.$ SubA) $-\mathrm{PRB}=>$ high $\mathrm{Hg}^{\circ}$ & 2 & High $\mathrm{NO}_{\mathrm{x}}$ furnace operation \\
\hline 3 & Galatia HvAb - high chlorine content & 3 & Unburned carbon present in the ash \\
\hline 4 & North Dakota Lignite & 4 & Spiking $\mathrm{SO}_{2}$ gas \\
\hline \multicolumn{2}{|r|}{ Oxidants / Additives } & 5 & Spiking Chlorine as $\mathrm{Cl}_{2}$ and $\mathrm{HCl}$ \\
\hline 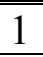 & Calcium Hypochlorate & 6 & Cooling Rate Modifications \\
\hline 2 & Sodium Tetrasulfide & \multicolumn{2}{|r|}{ Sorbents } \\
\hline 3 & Permanganates & 1 & Kaolinite/Hydrated Lime mixtures \\
\hline 4 & Ozone & 2,3 & Optimized designer sorbents \\
\hline
\end{tabular}

Table 8. Matrix of Experiments for Year 2 of the Project.

\begin{tabular}{|c|c|c|c|c|c|}
\hline Test Week & Coal Type & SFV & Oxid. / Addit. & Sorbents & Injection Temperature \\
\hline 1 & 1 and 2 & & $1,2,3,4$ & 1 & $\mathrm{H}, \mathrm{M}, \mathrm{L}$ \\
\hline 2 & 1 and 2 & & 1 and 2 & $1,2,3$ & $\mathrm{H}, \mathrm{M}, \mathrm{L}$ \\
\hline 3 & $1,2,3$ & $3,4,6$ & & 1 or 2 & Optimized, L \\
\hline 4 & $1,2,4$ & $1,2,4$ & & 1 or 2 & Optimized, L \\
\hline
\end{tabular}

Note: $\mathrm{H}=\operatorname{High}\left(900\right.$ to $\left.1200{ }^{\circ} \mathrm{C}\right), \mathrm{M}=\operatorname{Medium}\left(130\right.$ to $\left.800{ }^{\circ} \mathrm{C}\right), \mathrm{L}=\operatorname{Low}\left(\sim 80\right.$ to $\left.100{ }^{\circ} \mathrm{C}\right)$. 
The matrix of experiments for year two will produce approximately 60 data points toward optimization of the most promising calcium-based sorbent mercury emission mitigation strategy. As shown in the matrix, oxidant added separately from the sorbent will be investigated and optimized. Also, other means to effect oxidation, without additives, will be examined and optimized, particularly combustion modifications and cooling rate alterations. The matrix of experiments for the final year of this project will be developed based on the findings of the experiments conducted in years one and two of the project. The emphasis of this final year matrix, as with the entire project, will be to elucidate the fundamental mechanisms governing this mercury emission mitigation technology, as well as optimize the approach.

\section{Conclusions}

1) PSA monitor measurements were validated by Ontario Hydro measurements from a particulate free flue gas.

2) Ontario Hydro measurements were found to be inappropriate for measuring mercury speciation from particulate-laden flue gas.

3) ARCADIS proprietary sorbents were found to behave differently in the CRF then in the benchscale apparatus. Less total mercury was captured than expected, and the oxidant was ineffective. The major differences in conditions in the CRF were (1) mixed sorbent and fly ash instead of $100 \%$ sorbent, and (2) flue gas composition, i.e., presence of $\mathrm{NO}_{\mathrm{x}}$ and $\mathrm{CO}$, and higher $\mathrm{SO}_{2}$ levels.

4) Ordinary hydrated lime was found to be effective at capturing oxidized mercury on the bags of the baghouse.

5) Ordinary hydrated lime also was able to capture approximately $33 \%$ of the total mercury above $163{ }^{\circ} \mathrm{C}\left(325^{\circ} \mathrm{F}\right)$, while the sorbent was dispersed in the flue gas, before the baghouse.

6) Above $288{ }^{\circ} \mathrm{C}\left(550^{\circ} \mathrm{F}\right)$, no capture of mercury by hydrated lime occurred.

7) Simultaneous capture of $\mathrm{SO}_{2}(\sim 50 \%)$ from the high temperature flue gas and 80 to $90 \%$ of the mercury in the baghouse $\left(132{ }^{\circ} \mathrm{C}\right)$ was obtained by injecting ordinary hydrated lime right after the overfire air $\left(1150{ }^{\circ} \mathrm{C}\right)$.

8) High temperature $\left(1150{ }^{\circ} \mathrm{C}\right)$ injection of ordinary hydrated lime, which has been known to react with chlorine above $1000^{\circ} \mathrm{C}\left(1800{ }^{\circ} \mathrm{F}\right)$ to form calcium chloride, did not alter the mercury speciation downstream of sorbent injection. No elemental mercury was captured.

9) Future work will look at other common sorbents and alternative ways to oxidize elemental mercury.

\section{References}

1. Ghorishi, S. B. and Gullett, B. K., "Sorption of Mercury Species by Activated Carbons and Calcium-based Sorbents" Waste Manage. \& Res., 1998, 16(6) 582-589.

2. Ghorishi, S. B. and Sedman, C. B., "Low Concentration Mercury Sorption Mechanisms and Control by Calcium-based Sorbents" J. Air \& Waste Manage. Assoc., 1998, 48, 1191-1198.

3. Ghorishi, S. B., Singer, C. F., and Sedman, C. B., "Preparation and Evaluation of Modified Lime and Silica-Lime Sorbents for Mercury Vapor Emissions Control" Proceedings of the $2^{\text {nd }}$ EPRI-DOE-EPA Combined Utility Air Pollutant Control Symposium, Atlanta, GA, 1999. 